Summer 2004

\title{
Toward Global Democracy: Thoughts in Response to the Rising Tide of Nation-to-Nation Interdependencies
}

Hassan El Menyawi

Harvard Law School

Follow this and additional works at: https://www.repository.law.indiana.edu/ijgls

Part of the International Law Commons

\section{Recommended Citation}

El Menyawi, Hassan (2004) "Toward Global Democracy: Thoughts in Response to the Rising Tide of Nation-to-Nation Interdependencies," Indiana Journal of Global Legal Studies: Vol. 11 : Iss. 2 , Article 3. Available at: https://www.repository.law.indiana.edu/ijgls/vol11/iss2/3

This Article is brought to you for free and open access by the Law School Journals at Digital Repository @ Maurer Law. It has been accepted for inclusion in Indiana Journal of Global Legal Studies by an authorized editor of Digital Repository @ Maurer Law. For more information, please contact rvaughan@indiana.edu.

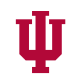

JEROME HALL LAW LIBRARY

INDIANA UNIVERSITY

Maurer School of Law
Bloomineton 


\title{
Toward Global Democracy: Thoughts in Response to the Rising Tide of Nation-to-Nation Interdependencies
}

\author{
Hassan El Menyawi*
}

\begin{abstract}
“De cette manière, l'État-Nation, qui a intégré sa population par la participation démocratique, gâche sa conquete la plus essentielle [à cause de l'internationalisation du monde]." [In this manner, the nation-state that has integrated its population through democratic participation loses its most essential conquest, because of globalization].
\end{abstract}

\footnotetext{
*Visiting Scholar, Harvard Law School, (2003-2004). I would like to thank Jose Correa (President of Doublevision) who provided me with many outstanding comments about this article. I would also like to thank my mentors Craig Scott (Dean and Associate Professor, Osgoode Hall Law School, Toronto, Ontario) who has assisted with revisions and provided challenging comments while remaining very enthusiastic about my ideas, and who is persistently encouraging me to pursue my ideas and Professor Richard Janda for his constant support of all my projects, always providing suggestions and great advice about my ideas. I wish to further thank Professors Janet Halley, Jerry Kang, David Kennedy (Director of the European Community Law Center), Henry Steiner (Director of the Human Rights Center), Franck Vogel (Director of the Islamic Law Center), all of Harvard Law School, as well as anonymous reviewers, for their continuous encouragement and confidence. I would also like to thank Professor Stephen Toope, who is the Director of the Trudeau Foundation and formerly Dean of McGill University, and Professor David Lametti, Director of the Comparative Law Institute of McGill University, who have believed in me, constantly pointing out that my research is not only relevant, but important at this point in international history.

An earlier version of this article was presented at a graduate seminar at Osgoode Hall Law School. I wish to thank participants at those sessions for their valuable comments, in particular Adam Vasey. I would also like to thank Obiora Okafor and Professor Liora Salter of Osgoode Hall Law School, for their comments and encouragement on an earlier version of this text, and their ongoing interest in my work in international democracy. I would like to thank Juan Castro, Visiting Scholar, Harvard Law School (2003), who, at the end of my research, and in spite of his admiration of the theory elaborated herein, enthusiastically provided a substantive critique of my ideas, which has reoriented my thoughts. Research support was generously provided by Osgoode's Hallett Scholarship and Harvard Law School (in the latter part of my research). Finally, I would like to thank Harvard Law School for allowing me to present related ideas in the Colloquium Seminar in December 2003.

1. Jürgen Habermas, L'État-Nation Européen: Passé et Avenir de la Souveraineté et de la Citoyenneté, in L'Intégration Républicaine: Essais de Théorie Politique 95, 115 (Rainer Rochlitz trans., 2000).
} 
"[Institutions at the international level need] to look through [their] member nations into the eyes of the world's peoples."2

\section{INTRODUCTION}

Accompanying the growing intensity of globalization, nation-to-nation interdependencies are on the rise, meaning that events and decisions in one nation increasingly have effects in other nations. At times, these interdependencies are negative, such as a recession that travels to North America after the onset of an economic bust in the Far East. Yet although nations' destinies are increasingly interconnected, their populations do not communicate with one another prior to making collective decisions, although those same decisions might negatively impact another nation. National democratic institutions are generally designed in ways that only allow citizens to vote in elections and to send representatives to legislatures, allowing no guarantee that the views of foreign populations will be considered. In fact, no national democracy has ever allowed foreigners to vote or send voting representatives to its legislature.

In light of increasing interdependencies among states, it has become important to design a system of global ${ }^{3}$ democracy. Such a system could provide national populations with opportunities to communicate with one another that would allow them collectively to minimize negative interdependencies. Without a new design, national populations will continue to impose their will (or the effects of their decisions) on other nations, in turn reducing their potential for national autonomy.

In this article, I discuss the possibility of designing an international democratic system. Since my project is to design institutions, it differs from the work of such scholars as Anne-Marie Slaughter. ${ }^{4}$ Slaughter has written extensively on how nations influence and create interdependencies with one another at the global level, noting the interlocking effects on legal and political structures and

2. Jeffery Atik, Democratizing the WTO, in Symposium, Global Trade Issues in the New Millennium, 33 Geo. WASH. INT'L L. Rev. 451, 472 (2001).

3. I use the words "global" and "international" interchangeably, to denote phenomena occurring between or among nations and beyond the scope of national boundaries-I do not use "international" strictly in the legal sense of bilateral or multilateral international treaties.

4. See generally Anne-Marie Slaughter, The Real New World, 76 Foreign Aff., Sept.-Oct. 1997, at 183, 183-84 [hereinafter The Real New World]; Anne-Marie Slaughter, A New World Order (2004). 
relationships. She focuses on describing events occurring at the global level, whereas mine is a normative project, attempting to re-design the operations of the global level. She, for example, argues that

the state ... is disaggregating into its separate parts, functionally distinct parts. These parts-courts, regulatory agencies, executives, and even legislatures-are networking with their counterparts abroad, creating a dense web of relations that constitutes a new, transgovernmental order. Today's international problemsterrorism, organized crime, environmental degradation, money laundering, bank failure, and securities fraud—created and sustain these relations. ${ }^{5}$

Slaughter thus documents trends and phenomena occurring at the global level. My approach, while in factual agreement with Slaughter about increasing interdependencies, has a prescriptive turn. My approach suggests new structures-new institutions - designed to deal effectively with the rise of nation-tonation interdependencies.

One way to move to a more legitimate international legal system that addresses the rise of interdependencies is to facilitate national populations' communication with one another. In other words, greater communication helps to move toward a democracy that includes the populations of all nations, linking them together. ${ }^{6}$ Indeed, there is a growing scholarly literature pointing to the need for a democratic conception of international relations and law, supplemented with the fact that a tide of democratic change has swept the world. ${ }^{7}$ As represented in the quotation above, the political philosopher Jürgen Habermas

5. The Real New World, supra note 4, at 184.

6. I use the terms "national populations" and "populations of nations" interchangeably. The term "populations of nations" connotes a disaggregated set of persons- of citizens inside the nation-state, so I refer to them as populations of nations. However, these words are not to be confused with the word "nation," which is a more general term, potentially including the population of the nation-state, while also including the "state" as a political body.

7. See generally Thomas M. Franck, Fairness in International. Law and Institutions ch. 4 (1995) [hereinafter Fairness in International Law]; Michla Pomerance, Self-Determination in Law and Practice: The New Doctrine in the United Nations (1982). See also Thomas Franck, The Emerging Right to Democratic Governance, 86 AM. J. INT'L L. 46 (1992) [hereinafter Emerging Right to Democratic Governance]; D.A. Rustow, Democracy: A Global Revolution?, 69 FOREIGN AfF. 75 (1990). 
laments the absence of international democracy, after the great historical quest nations have undergone to achieve national democracy. Why not then consider democratic structures as a basis for international governance?

Several international relations theorists, political philosophers, and democracy scholars have attempted to reorient the literature on international relations, and contemplate the institutional implementation of international democracy. These include David Held, Thomas Franck, Michael Reisman, and Habermas. Michael Barkun in the 1960s and Joseph Weiler in 2000 cautioned scholars not to "adopt national or domestic analogies" as a starting point or explanatory model for the international level; ${ }^{8}$ scholars generally disregard this advice. ${ }^{9}$

In light of these points, the goal of this article is to make design proposals to democratize the international level in the same way as Franck, who refers to international design as "rethinking structure." 10 The renowned social science philosopher Mario Bunge points out that the project of institutional design presupposes an understanding of the problems of current institutions, and that it is an "imaginative yet potentially feasible vision of society" that allows for advancements in social relations."

Although I say that I intend to explore institutional design, ${ }^{12}$ it is most definitely not my intent to evaluate all our contemporary "international" structures, indicate their problems, and recommend some possible proposals that could potentially stimulate alternative designs of the international system. In other words, while the ultimate goal is to design a complete, justified, and democratic set of international institutions, this article is meant solely to start the engine, rather than arrive at a final destination. And, as a starting point I argue that any design proposals for international democracy should preserve the autonomy of nations, yet allow the world's national populations to communicate with one another.

8. See generally Michael Barkun, Law Without Sanctions: Order in Primitive Societies and the World Community 10-12 (1968). See Joseph H. Weiler, The Constitution of Europe 264 (1999).

9. More specifically, when scholars speculate about international democratic institutions, they tend to favor designs that are similar to existing national legislatures. In other words, they call for a single assembly, with representatives elected from each nation in the world.

10. See Fairness in International Law, supra note 7, at 481.

11. See Mario Bunge, Social Science Under Debate: A Philosophical Perspective 439-41 (1999).

12. I use the terms "institution design" and "institutional design" interchangeably. 
The most typical, yet perhaps least realistic, institutional design suggestion is to establish a world government or single global assembly. Rather than develop a democracy for all nations in a single global assembly, it might be more appropriate to develop democracy by linking (either among or between) ${ }^{13}$ national populations without bringing them together under a single roof, where smaller nations might be overwhelmed by larger ones and prompted to cede their sovereignty. Linked national populations, by contrast, have the opportunity to "look into each other's eyes." This distinction might at first seem to be trivial, but after working and reflecting on this question for over a year, I consider this linkage of populations to be a key requirement for institutional design. Elucidating this notion is the goal of this article.

In Part I, I describe what I mean by interdependencies, and then describe what type of legitimacy and structural criteria are required to begin to think about international institution design.

In Part II, I first describe the two design criteria I use when thinking about democratic international institution design; the first is that the autonomy of nations should be preserved, and the second is that the division, referred to most notably by Richard Falk and Andrew Strauss as "bifurcation," that separates the populations of nations from each other should be reduced or eliminated. In Part II.B, I describe some of the more prominent paradigms of international democracy, and evaluate their potential to address the design criteria set out in the preceding section. I conclude with Habermas' public deliberation model of democracy and use it as a guide to inspire democratic institution design.

Finally, in Part III, I discuss several design proposals. I begin by exploring ways to conceive of international systems, and conclude that the development of a system that respects the political and cultural autonomy of nations, while still permitting active and productive connections linking nations' populations, should be the general goal of international institution design. These ideas should be seen as a starting point, a work in progress, to begin to think about alternative international institutions.

13. In this article, I typically use the words "between" populations of nations when referring to the separation (bifurcation) that exists between national populations as a result of the state-centric international system. When I attempt to remedy the problem, bringing national populations together, I typically refer to them as "linking" together. 


\section{A Call for International Democratic Design: A Way to Cope With Nation-to-Nation INTERdEPENDENCIES}

In the past, nations of the world were less interdependent than they are today. Globalization has altered that earlier pattern, essentially tying the destinies of separate nations together. ${ }^{14}$ As one commentator states, globalization is a process "extending the determinative frameworks of social change to the world as a whole." ${ }^{5}$ This is reflected in Habermas' description of globalization: "La condensation de relations établies a l'échelle mondiale, par suite de laquelle certains évènements locaux, tres éloignés les uns des autres, exercent les uns sur les autres une action réciproque." [The condensing of relationships established on a global scale, after which certain local events, each very far away from one another, all exercise one on top of the other a reciprocal action. $]^{16}$

Globalization processes have produced an unprecedented degree of interconnectedness, and therefore, produced a dependency between nations, which I interchangeably refer to as international dependencies or interdependencies. ${ }^{17}$ These global interdependencies potentially have significant positive and negative effects. The positive benefits include facilitation of technical and social creativity, the spread of beneficial technologies, the understanding of cultures, the growth of economies, ${ }^{18}$ etc. ${ }^{19}$ Legal scholars such as Slaughter see evidence of "judicial globalization" in an increasing amount of constitutional cross-fertilization, whereby

14. See, e.g., Sol Picciotto, Networks in International Economic Integration: Fragmented States and the Dilemmas of Neo-Liberalism, 17 Nw. J. Int'L L. \& Bus. 1014 (1996-97); David KNoke, PolitiCal Networks: The Structural Perspective 76-81 (1990).

15. Zdravko Mlinar, Individuation and Globalization: The Transformation of Territorial Social Organization, in Globalization and Territorial Identities 15, 19 (Zdravko Mlinar ed., 1992).

16. Habermas, supra note 1, at 111-12. See also Anthony Giddens, The Consequences of Modernity 64 (1990); Anthony Giddens, Beyond Left and Right 78 (1994).

17. See David Held, Democracy and the Global Order: From the Modern State to Cosmopolitan Governance 16-17 (1995). See generally Aihwa Ong, Flexible Citizenship: The Cultural Logics of Transnationality 214 (1999).

18. See Gilles Bourque et al., L'Incorporation de la Citoyenneté, 31 Sociologie et Socrétés 41 (Automne 1999); Robert Wolfe, Embedded Liberalism as a Transformation Curve: Comment, in THE Nation State in a Global Information Era: Policy Challenges 83 (Thomas J. Courchene ed., 1997); Mark W. Zacher, The Global Economy and the International Political Order: Some Diverse and Paradoxical Relationships, in The Nation State in a Global Information Era: Policy ChalLENGES, supra, at 67.

19. See Daniel M. Downs \& Richard Janda, Virtual Citizenship, 13 Can. J. L. \& Soc'y 27 (1998). 
courts look for guidance in the decisions of constitutional courts around the world. ${ }^{20}$

Some scholars cite examples of interdependencies that seem particularly useful, or at least neutral, for national populations. However, some interdependencies can be very destructive if uncontrolled. Consider ecological issues, or the new forms of exploitation, inequality, and de-solidarization generated by an intensely competitive globalized market. ${ }^{21}$

Global interdependencies, both of the good and the bad variety, are by definition experienced between nations, such that if the economy of nation $\mathrm{X}$ is performing poorly or well, it has direct and indirect effects on the economy of nation Y. Such interdependencies have been cultural as much as they have been economic. For example, consider ethnic strife, which, when it occurs in a particular nation, has the potential to destabilize a region and spread to other nations. ${ }^{22}$

As a result of these interdependencies, doubts have emerged about the ability of nations to exclusively control developments directly affecting their citizens' lives; the legitimacy of international relations thus has become an issue of central concern. In order to manage new interdependencies, nations will likely have to work together through international institutions, both to curb negative effects, as well as properly distribute positive effects, and thereby protect their mutual autonomies. ${ }^{23}$ One commentator closely reflects this thought:

The globalization of the world economy, the ever closer knitting of the world together through telecommunications, the Internet, global popular culture, mass travel and tourism, the global nature

20. Anne-Marie Slaughter, Judicial Globalization, 40 VA. J. INT'L L. 1103, 1115 (2000) (citing Nanus Asia Co. v. Standard Charter Bank, 1988 H.K.C. LEXIS 410, at *1, *8 (High Ct. Sept. 22, 1988)).

21. See Roderick A. MacDonald, Entre l'Efficience de Justinien et la Justice de Locke, 41 LEs Cahiers de Droit 171 (2000); Ong, supra note 17, at 214-17; Robert Wolfe, Embedded Liberalism as a Transformation Curve: Comment, in The Nation State in a Global Information Era: Policy Challenges, supra note 18, at 83; Zacher, supra note 18, at 67.

22. See generally Hannah Arendt, The Origins of Totalitarianism (1973); Rogers Brubaker, Citizenship and Nationhood in France and Germany (1992); Jean L. Cohen, Class and Civil Society: The Limits of the Marxian Critical theory (1987); Maurizio Viroli, For Love of Country (1995).

23. See Part II infra, for the meaning of autonomy in this context. 
of problems such as environmental degradation and control, international drugs, crime and terrorism, the global movement of capital, labor, and their attendant periodic contagions and crises, and the interdependence of economies, states, and peoples will give rise to never ending pressures to develop viable global processes and institutions to cope with such globalization and interdependenc [ies]..$^{24}$

To cope with these interdependencies, global processes and institutions would have to be designed. Such (hypothetical) global institutions would have to be legitimate, as Robert Sheppard points out when he states that:

$[\mathrm{O}] \mathrm{n}$ the basis of free flows of capital and goods, accompanied by occasional crises uch as the recent Asian Economic Crisis, national governments now realize there is no way to establish independent

24. Robert Sheppard, Towards a U.N. World Parliament: U.N. Reform for the Progressive Evolution of an Elective and Accountable Democratic Parliamentary Process in U.N. Governance in the New Millennium, 1 Asian-PAc. L. \& PoL'y J. 19 (2000), available at http://www.hawaii.edu/aplpj/pdfs/ 04-sheppard.pdf. See also Held, supra note 17, at 16-17. Held states:

The very process of governance can escape the reach of the nation-state. Nation[states] by no means exclusively make and determine decisions and policies for themselves, and governments by no means determine what is appropriate exclusively for their own citizens . ... To make some topical examples: a decision to increase interest rates in an attempt to stem inflation or exchange rate instability is most often taken as a 'national' decision, although it may well stimulate economic changes in other countries. A decision to permit the 'harvesting' of the rainforests may contribute to ecological damage far beyond the borders which formally limit the responsibility of a given set of political decision-makers. A decision to build a nuclear plant near the frontiers of a neighboring country is a decision likely to be taken without consulting those in the nearby country (or countries), despite the many risks and ramifications for them. A decision by a government to save resources by suspending food aid to a nation may stimulate the sudden escalation of food prices in that nation and contribute directly to an outbreak of famine among the urban and rural poor. These decisions, along with policies on issues as diverse as investment, arms procurement, and AIDS, are typically regarded as falling within the legitimate domain of authority of a sovereign nation-state. Yet, in a world of regional and global interconnectedness [and interdependencies], there are major questions to be put about the ... viability and accountability of national decision-making entities themselves.

Id. 
national strategies in economic and social fields and to ignore the rest of the world and the interdependency of the global economy. Nation-states will increasingly need to manage such interdependency such that they are advantaged [(through positive interdependencies)] rather than victimized by it [(through negative interdependencies)] and will need to form new and reliable institutions of cooperation and governance to deal with realities beyond their control that may otherwise cripple them. Those institutions will [have to produce] ... global legitimacy .... ${ }^{25}$

Furthermore, this need for global institutions is not specific to nations of a particular size or power, as stated in Sheppard's quotation, given that interdependencies are arguably intense enough to affect both small and large nations alike, even if not necessarily equal in intensity. Michael Reisman mirrors this when he states that

though the world of big and small and strong and weak states ... persists, the sharp asymmetries of 1945 have given way to complex international interdependencies. In this new world ... arrangements [at the international level] ... require more and more cooperation between large and small states. ${ }^{26}$

Indeed, coping with globalization and global interdependence requires institutions that would further and enhance international cooperation, but more than that, it requires appropriate international governance institutions, which allow nations to collaborate together to collectively control and effectively distribute negative and positive interdependencies. ${ }^{27}$ As Sheppard states, there is a need for greater global legitimacy. But there are many types of legitimacy. Which type would be most suitable? What are the central criteria for the design of global, legitimate institutions? I turn to these questions in the following sections.

25. Sheppard, supra note 24 , at 7-8.

26. Michael Reisman, The Constitutional Crisis in the United Nations, 87 AM. J. INr'L L. 83 (1993).

27. See Helen Stacy, Relational Sovereignty, 55 Stan. L. Rev. 2029, 2056 (2003) (stating that "globalization has brought both positive and negative effects, and that these have not been evenly distributed across and within nation states.") (emphasis omitted). 


\section{A. Interdependencies and Legitimacy}

Because nation-to-nation interdependencies have created a need to think about legitimacy, I next examine the idea of legitimacy and decide what definition of it is appropriate in the context of institution design. I do this to guide my discussion of institution design, since how one characterizes legitimacy is likely to have downstream effects on how an institution is designed.

There are many types of governance-consider monarchy, authoritarianism, and democracy. ${ }^{28}$ Theories of legitimacy attempt to specify what factors might serve as justifications for these types: tradition, rationality, legality, order, and of course, democracy, to name a few..$^{29}$

The term "legitimacy" has been used in various ways and so it is important to explain what is meant by it here. Sometimes "legitimacy" connotes "genuineness." Consider for example when someone says that "the situation in Rwanda is a legitimate emergency." But legitimacy is also used to connote "justification," as when someone points out that a person "raised a legitimate concern." Such a statement means that this person is justified in saying whatever it is he said. ${ }^{30}$

When referring to legitimacy, I mean it in the latter sense of being justified. There are many definitions of legitimacy that are based on the idea of justification. Consider Habermas's definition: "Legitimacy means that there are good arguments for a political order's claim to be recognized as right and just; a legitimate order deserves recognition. Legitimacy means a political order's worthiness to be recognized." 31

Although there are many other definitions of legitimacy, ${ }^{32}$ it seems that Habermas's represents a definition that is consistent with the project of this

28. See generally Daniel Bodansky, The Legitimacy of International Governance: A Coming Challenge for International Environmental Law?, 93 AM. J. INT'L L. 596 (1999) (discussing the system of democracy).

29. Id. at 601 .

30. See id. at $600 \mathrm{n} .26$ (defining legitimacy as "genuine" and "justified").

31. Jürgen Habermas, Communication and the Evolution of Society 178 (Thomas McCarthy trans., 1979) (emphasis omitted).

32. See Bodansky, supra note 28 , at $601 \mathrm{n} .29$ (discussing representative definitions of legitimacy); Archibald Cox, The Role of the Supreme Court in American Government 103 (1977) (legitimacy is the ability "to command acceptance and support from the community so as to render force unnecessary"); Robert A. Dahl, Modern Political Analysis 41 (2d ed. 1970) (“A government is said to be 'legitimate' if the people to whom its orders are directed believe that the structure, 
article. The argument laid out above is that as a result of the increasing rise of nation-to-nation interdependencies, there is a need to rethink international structures and design alternative ones. The argument is that it is not just that some national populations are the recipients of the consequences of another nation-state's decisions and actions (whether or not they were intended). In in Habermas' words, such a system does not "deserve recognition" as a legitimate order that is both "right and just." 33

Of course, it is one thing to claim that an order is illegitimate, but it is altogether another to say what system should replace it (what system deserves recognition). Indeed, this is one of the central topics of this article-to outline what criteria should be considered when designing institutions for the international level. As we will see, these include democracy, the preservation of national autonomy, and the shrinking of the divide between the populations of nations.

Institutional legitimacy is also referred to as "process legitimacy" by scholars such as Thomas Franck, who view institutions as part of a "rule-making... process." 34 The project of redesigning institutions' processes in response to the illegitimacy (or reduced legitimacy) of currently existing institutions is sometimes referred to as "making [institutional] reforms" 35 or "designing" institutions. ${ }^{36}$

procedures, acts, decisions, policies, officials or leaders of government possess the quality of 'rightness,' propriety or moral goodness - the right, in short, to make binding rules."); SEYMour MARtin Lipset, Political Man: The Social Bases of Polirics 77 (1960) (legitimacy means "the capacity of the system to engender and maintain the belief that the existing political institutions are the most appropriate ones for the society"); Joseph Raz, Authority and Justification, 14 PHIL. \& Pub. Aff. 3, 5 (1985) (stating that institutions have "legitimate authority only if and to the extent that their claim [to have a right to rule] is justified"). But $c f$. Thomas Franck, The Power of Legirmacy Among Nations (1990) (examining the effective authority of individual legal norms, rather than the justification of international institutions or decision-making processes).

33. Id.

34. See Fairness in International Law, supra note 7, at ch. 2. Process legitimacy is typically pitted against "substantive legitimacy": where the former refers to how rules come to be, the latter is about the content of such rules. Process legitimacy does not depend on whether a rule or decision is substantively correct (judged by whatever standard); rather, it reflects more general support for a regime, which makes subjects willing to substitute the regime's decisions for their own evaluation of a situation. Hence, process legitimacy refers to ongoing systems of governance-on the institutions that issue directives, and the processes by which they do so-rather than on the legitimacy of particular directives.

35. Mario Bunge uses the expression "making reforms" and "reform" interchangeably with "making institutional changes" or "changes." See Bunge, supra note 11, at 442-43.

36. See W. Michael Reisman, Redesigning the United Nations, 1 Sing. J. InT'L \& Comp. L. 1,8 (1997). 
Consider David Caron's work arguing that the United Nations Security Council lacks legitimacy, since it does not represent the nations of the world, but represents only a few members: fifteen members are on the Council, ten are rotating, and five members are permanent, each enjoying the power to veto a potential resolution. ${ }^{37}$ There are also more sweeping arguments for change. Consider Franck, who recommends that the United Nations General Assembly be transformed into a two-chamber body, one that that contains representatives appointed by states similar to the way that it is constituted at present, and a second chamber that contains representatives that are directly elected in accordance with universal suffrage and democratic principles.

Although "institutional legitimacy" is, as Franck describes, based on "process," it is inextricably related to the substantive legitimacy of the rules that the institution is likely to produce, since rules emerge from the interactions and processes of an institution. ${ }^{38}$ This type of legitimacy is typically referred to as "rule legitimacy." ${ }^{39}$ Rule legitimacy is the notion that rules are seen as legitimate if they are a product of a legitimate process. ${ }^{40}$ Hence, discussion about institutional legitimacy is also partly a discussion of rule legitimacy-considering that how the institution operates and is seen is likely to have effects on how its rules are seen from a legitimacy perspective. ${ }^{41}$ Franck agrees, stating that the "legitimacy in the rules ... [is dependent on] the way they are made, ${ }^{, 42}$ even if this goes too far in ignoring the self-standing legitimacy of rules from a substantive point of view.

\section{B. Two Types of Institutional Legitimacy}

When discussing institutional legitimacy, it is important to mention that it can be seen to have both a descriptive, sociological, or popula ${ }^{43}$ and a normative,

37. See generally David Caron, Governance and Collective Legitimation in the New World Order, 6 Hague Y.B. Int'L L. 29 (1993).

38. Obiora Okafor, The Global Process of Legitimation, 14 Ariz. J. of INT'L \& Comp. L. 117, 133 (1997).

39. Id.

40. Id.

41. Id.

42. Thomas Franck, Why A Quest for Legitimacy?, 21 U.C. Davis L. Rev. 535 (1988).

43. This type of legitimacy is referred to as descriptive legitimacy, popular legitimacy, or sociological legitimacy. I use these words interchangeably. 
evaluative, or prescriptive ${ }^{44}$ dimension. Reform is typically associated with an evaluative legitimacy and so it is important to discuss the idea. To do this, though, it is equally important to discuss its counterpart, descriptive legitimacy.

Descriptive legitimacy was first described by Max Weber, who saw legitimacy as a measure of the belief of the concerned polity in the right of their leadership to lead, no matter how that belief was secured. ${ }^{45}$ In Habermas' view, descriptive legitimacy refers to popular attitudes about whether a particular institution should be recognized as worthy, as right and just. ${ }^{46}$ The recognition that an institution is just, if the subjects to whom it is addressed accept it as just, is popular legitimacy. ${ }^{47}$ The more positive the public's attitudes about an institution's right to govern, the greater its popular legitimacy.

On the other hand, institutional legitimacy can also have a normative meaning when the institution's recognition as just is "well founded." ${ }^{\text {48 }}$ Normative legitimacy seeks to go beyond the sentiments of people, even if the majority within society believes something to be legitimate, and to evaluate a particular form of governance based on specific criteria external to the sentiments and beliefs of the majority. ${ }^{49}$ For many scholars who contemplate international legitimacy and reform or design of the international system, questions of legitimacy are addressed in this evaluative sense. Consider the works of Habermas, Held, and Michael Saward. ${ }^{50}$ In this article, I also adopt an evaluative sense of legitimacy-in fact, I would argue that developing an institution design requires evaluative legitimacy. Since my project is about institution design, it reflects an evaluative legitimacy orientation.

44. This type of legitimacy is referred to as normative legitimacy, evaluative legitimacy, or prescriptive legitimacy. I use these terms interchangeably.

45. See generally Max Weber, Economy and Society (Guenther Roth and Claus Whittich eds., 1978) (1914); I. Horowitz, The Norm of Illegitimacy - Ten Years Later, Legitimation of Regimes: International Framework for Analysis 23 (B. Denitch ed., 1979); J. H. Schaar, Legitimacy in the Modern State 15 (1981).

46. See id.

47. See Bodansky, supra note 28 , at 601.

48. Id.

49. See Hanna Pitkin, Obligation and Consent - II, 60 Am. PoL. ScI. Rev. 39 (1966) ("Legitimate authority is precisely that which ought to be obeyed....").

50. See generally Jürgen Habermas, Legitimation Crisis (Thomas McCarthy trans., 1975); David Held, Power and Legitimacy in Contemporary Britain, in State and Society in Contemporary Britain: A Critical Introduction 302 (Gregor McLennan et al. eds., 1984); Michael Saward, Co-optive Politics and State Legitimacy 33 (1992). 
If institution design is seen through an evaluative legitimacy lens, then it is essential to determine what the specific criteria are for any design project, before outlining the actual institutional design. Michael Reisman refers to criteria based on evaluative institutional legitimacy as "design principles."

Design principles (or evaluative legitimacy criteria) may vary, depending on the political or philosophical system they are based on-from the works of John Locke and Thomas Jefferson, to the ideas of the Qur'an. Which system one adopts produces different design principle outputs. In the case of the particular project of international institution design, the single most important criterion is that the institutions be democratic. In the design of a democratic institution at the international level, there are two other criteria that I consider essential, and that I turn to in the first section of the next part: preserving the political and cultural autonomy of nations, and ensuring that nations' populations are afforded the opportunity to deliberate with each other. But, for now, let me turn to why democracy is an important criterion.

\section{Democracy as Institutionally Legitimate}

As a type of institutional legitimacy, democracy seems to be an ideal design principle when thinking about the international level. Many scholars today see legitimacy and democracy as tantamount, and increasingly, the national populations of the world see it as a "global entitlement." " And, although dissatisfaction with democracy is common in Western countries, ${ }^{53}$ it is still fair to say that democracy is seen as legitimate when compared to its alternatives, probably due to the fact that democracy is seen as "produc[ing] the best results"--either because, as Jefferson argued, "in the end, the people are wiser than any single individual

51. See Reisman, supra note 36, at 8.

52. See Fairness in International Law, supra note 7, at 83-139; Pomerance, supra note 7; Emerging Right to Democratic Governance, supra note 7, at 46; see also Bodansky, supra note 28, at 599 (discussing how democracy and legitimacy strongly inter relate and are even equated with one another); Rustow, supra note 7, at 75 (analyzing several recent conversions toward democracy and suggesting how such democratic changes could be more successful and sustainable). But see Lauri Hannikainen, Peremptory Norms (Jus Cogens), in International Law: Historical Development, Criteria, Present Status 375 (1988) ("[O]ne cannot speak of the universal right of dependent peoples to self-determination.") (emphasis omitted).

53. See Bodansky, supra note 28, at 599. See generally Michael J. Sandel, Democracy's Discontent: America in Search of a Purlic Philosophy (1996) (discussing the tensions inherent between democracy in practice and the public philosophy behind democracy). 
can be," or because democracy best aggregates individual interests, as the utilitarians believe, thereby maximizing social welfare. ${ }^{54}$

Democracy is also a great mechanism for communication. As mentioned above, the goal of institution design is for nations to find ways to collectively manage interdependencies. Hence, democracy is ideal, since it allows the populations of nations to communicate with one another, thereby providing for optimal results. By enabling the population of nations to communicate through democratic processes, the hope is that they will find ways to reduce or limit negative interdependencies, while increasing positive ones.

But, in addition to the fact that there is an increasing tide of interdependencies, instituting international democracy is seen by many scholars as an inherently worthy goal. In fact, as far back as 1966, Innis Claude recognized that popular consent is needed as a legitimizing principle of contemporary international political life and not simply national or local political life. ${ }^{55}$ Since then, many scholars have acknowledged the necessity of developing a people-centered or democratic conception of international law. ${ }^{56}$

54. Bodansky, supra note 28, at 613 (quoting Thomas Jefferson) (citation omitted). "Environmental politics provides empirical support for a substantive justification of democracy since Western liberal democracies have done a demonstrably better job of protecting the environment than the non-democratic regimes of the former Soviet Union and Eastern Europe." Id. at $613 \mathrm{n} .101$ (citing Robert Paehlke, Environmental Challenges to Democratic Practice, in Democracy and the Environment: Problems and Prospects 18, 19 (William M. Lafferty \& James Meadowcroft eds., 1996)).

55. Inis L. Claude, Jr., Collective Legitimization as a Political Function of the United Nations, 20 INT'L. Org. 367 (1966). See also Hugo Caminos, Effects of the New World Order on the Third World, 87 Am. Soc'y INT'L. L. Proc. 41 (1993); Gábor Kardos, Right to Peace, Right to Development, Right to a Healthy Environment: Part of the Solution or Part of the Problem?, in Human Rights in a Changing East-West Perspective 216, 220 (Allan Rosas \& Jan Helgesen eds., 1990); W. Michael Reisman, Sovereignty and Human Rights in Contemporary International Law, 84 AM. J. INT'L. L. 866, 867-68 (1990); Allan Rosas, Internal Self-Determination, in Modern Law of SelfDetermination 227 (Christian Tomuschat ed., 1993); Christian Tomuschat, Democratic Pluralism: The Right to Political Opposition, in The Strength of Diversity: Human Rights and Pluralistic Democracy 27, 40-44 (Allan Rosas \& Jan Helgesen eds., 1992).

56. See, e.g., Tom Athanasiou, Divided Planet: The Ecology of Rich and Poor 26 (1996); Bodansky, supra note 28, at 599 ("[D]emocracy [is] the touchstone of legitimacy in the modern world.") (emphasis in original); James Crawford, Democracy and International Law, 64 BRIT. Y.B. INr'L. L. 113 (1993); Hilary F. French, Strengthening International Governance, 3 J. of Env'T. \& Dev. 59, 65 (1994); Jochen Abr. Frowein, The European Community and the Requirement of a Republican Form of Government, 82 Mich. L. Rev. 1311, 1322 (1984); Patti Goldman, The Democratization of 


\section{Preliminary Definition of Democracy}

Whereas Hobbes vested all political power with the sovereign, however constituted ${ }^{57}$ Locke took a different position, vesting ultimate authority with the people. ${ }^{58}$ Inspired by Locke's position, democracy has become the hallmark of legitimate governance in the modern world. ${ }^{59}$ Locke's idea of democracy as "rule by the people" ${ }^{60}$ echoes in Franck's definition of democracy. "The term, democracy, as used in international rights parlance is intended to connote the kind of governance, which is legitimated by the consent of the governed." ${ }^{61}$ For Franck, it is difficult to consider a political institution as "democratic" without multi-party, regular, free elections based on universal suffrage. ${ }^{62} \mathrm{He}$ sees democracy as based on the will of the people, or the consent of the governed, expressed

the Development of United States Trade Policy, 27 ConNell INT'L L. J. 631, 643-48 (1994) (questioning legitimacy of WTO); Phillip R. Trimble, Globalization, International Institutions and the Erosion of National Sovereignty and Democracy, 95 Мıсн. L. REv. 1944, 1966 (1997) ("If international institutions are to acquire and exercise the sovereign powers required to respond to the negative forces of globalism, they ... will have to become more democratic."); David A. Wirth, Re-examining Decision-Making Processes in International Environmental Law, 79 IowA L. Rev. 769, 802 (1994).

57. Thomas Hobbes, Man and Citizen 165, 171 (Bernard Gert ed., Charles T. Wood et al. trans., 1972). See also Thomas Hobbes, Leviathan (Thoemmes, 2003) (1651).

58. John Locke, Two Treatises of Government, chap. VIII, para. 95-96 (Cambridge Univ. Press 1960) (1690).

59. See Bodansky, supra note 28 , at 612 (stating that democracy is a relatively recent phenomenon and, that, historically, governments usually claimed some other basis of legitimacy-divine right, tradition, or rule by the natural elite, to name a few). See also David Held, Models of Democracy (1987); C.B. Macpherson, The Real World of Democracy I (1966):

Democracy used to be a bad word. Everybody who was anybody knew that democracy, in its original sense of rule by the people or government in accordance with the will of the bulk of the people, would be a bad thing - fatal to individual freedom and to all the graces of civilized living. That was the position taken by pretty nearly all men of intelligence from the earliest historical times down to about a hundred years ago.

60. Susan Marks, International Law, Democracy, and the End of History, in Democratic Governance and International Law ch. 19 (Gregory H. Fox \& Brad R. Roth eds., 2000). See also Susan Marks, The Riddle of All Constitutions: International Law, Democracy, and the Critique OF IDEOLOGY (2000).

61. Fairness in International. Law, supra note 7, at 102, 477-84.

62. It is important not to ignore the fact that suffrage for women, and even for some religious or racial groups (such as African Americans in the United States), is a recent practice in many democracies. Thus far, the idea of universal suffrage has not included a nation's 'non-citizens'non-citizens are excluded, even if they work, live, or study in a host nation. 
through regular, free elections, in which leaders can be replaced and policies changed in response to voting processes. ${ }^{63}$

The above definition of democracy is only preliminary. In Part II, I come to a more precise definition of democracy-one that I consider appropriate for democratic institution design.

\section{In Search of International Law's Democratic Shoes}

In Part II.A, I examine two design principles for global democracy. Then in Part II.B, I examine different models of international democracy that have been discussed in the literature and determine whether they fit the design criteria enumerated and discussed in Part II.A.

\section{A. A Tale of Two Design Principles for Global Democracy}

\section{The Criterion of National and Cultural Autonomy}

The overarching goal of democratic international institution design is to allow nations the opportunity to manage their mutual interdependencies; increasing their positive interdependencies-the ones they want-while also reducing the negative ones. Hence, one can see this project of institution design as simultaneously recognizing the results of globalization that tie nations' fates together, while respecting, and even increasing, the autonomy of nations in light of these interdependencies. It is for this reason that I generally consider autonomy a crucial design criterion of democratic international institution design.

In order for hypothetical democratic international institutions effectively to deal with global interdependencies, it is important that national and cultural autonomy be protected, because national populations and nation-states are generally wary of institutions that might restrict their autonomy. Hence, democratic international institutions would have to be designed in ways which assure continued autonomy of nations, both small and large. I therefore turn to the question of national and cultural autonomy.

63. See, e.g., Fairness in International Law, supra note 7, at 482-84. See also Held, supra note 17, at 269-74 (proposing the establishment of a directly-elected "independent assembly of democratic peoples"). 
One of the major questions that has emerged in the context of the European Union (EU), which is bound to become a concern to nations contemplating the establishment of democratic international institutions, is the fear that that more powerful societies within the newly formed EU could potentially overpower smaller nations, thereby destroying their cultural and political autonomy. Consider what Weiler refers to as the Danes' "screams of grief," if Denmark were to be absorbed by Germany and Danes were consequently bound by the decisions of the German majority in the Bundestag. ${ }^{64}$ This is a worry that arises from fear that larger Member States, by simple reasons of size will dominate the EU, thereby producing a natural, even if gradual, erosion of cultural autonomy in smaller nations. ${ }^{65}$

Europeans typically voice their scepticism about joining the Union in three ways. First, that "the reach of the community or union into areas which are, or are thought to be, classical symbolic 'State' functions in relations to which 'Foreigners' should not be telling 'Us' (French or Danes or Irish, etc.) how to run our lives." These areas are socially constructed and culturally bound, and are not fixed. They range from the less serious (British Pint) to the crucially important and morally significant (the right-to-life of the Irish abortion saga). Second, that the reach of the Community or Union into areas which are, or are thought to be, matters left to individuals or local communities and in relation to which "government" should not be telling "Us" (the people) how to run their lives. ${ }^{67}$ And third, that the "perception, whether or not rooted in reality, that there is no effective limit and/or check on the ability of the Community or Union to reach into areas previously thought to be the preserve of the state or of the individual." 68

The same fears that Europeans experience with respect to the EU would likely arise for the populations of nations in the context of establishing international democracy, especially if international democracy implies the establishment of a single world state, or huge democratic assemblies, which make the voices of smaller nations inaudible relative to those of larger, more populated, nations, or force smaller nations to collaborate to overcome the power of larger

64. See WeILER, supra note 8.

65. Id.

66. Id. at 265 .

67. See id.

68. Id. 
nations. ${ }^{69}$ Either way, this process dilutes the autonomy of large and small nations. In some cases, large nations will likely be overwhelmed (and potentially outvoted) by the unified support of small nations, but ironically, this would also dilute the autonomy of smaller nations, which feel they must gain the support of other nations to overcome larger nations' power, ${ }^{70}$ thereby, effectively reducing their authentic voice, and hence, their autonomy.

Although citizens of nations generally see value in communicating with other nations to ensure peace and stability in the global arena, they are wary of institutions that require them to cede so much power to a single instance, because of the risk of loss of their effective independence, or their culture. ${ }^{71}$ Indeed, there seems to be consensus, after a long historical period marked by colonialism, that cultural and national values, and the preservation and continued expression of such values, have intrinsic worth. For the populations of many nations, these values represent the citizens' sense of being, their identity. ${ }^{72}$

69. I see qualifications such as "large" and "small" as being on a spectrum. To be precise, small nations are nations that have smaller populations when compared to another nation, or simply less power and influence. When considering these two definitional criteria, one can see Canada as smaller when compared to the United States. But, one can also see India as smaller than the United States with reference to military power, but not with respect to national population.

70. See Reisman, supra note 36, at 8 (arguing that it is important to take power into account when designing political institutions).

71. See Franck, supra note 32.

72. See Joseph H. Weiler, To be a European Citizen - Eros and Civilization, in ThE Constitution of Europe, supra note 8, at 324; Declaration on the Granting of Independence to Colonial Countries and Peoples, U.N. GAOR, 15th Sess., Supp. No. 2, at 66, U.N. Doc.A/Res/1514(XV) (1960); Banjul Charter on Human and Peoples' Rights, June 26, 1981, 21 1.L.M. 59, art. 20; Declaration on Principles of International Law Concerning Friendly Relations and Co-operation Among States in Accordance with the Charter of the United Nations, Oct. 24, 1970, 9 I.L.M.1292; International Covenant on Economic, Social, and Cultural Rights, Dec. 19, 1966, 6 I.L.M. 360, art. 1; International Covenant on Civil and Political Rights, Dec. 16, 1966, 6 I.L.M. 368, art. 1; see also Franck, supra note 32 (examining the effective authority of individual legal norms); Frederic L. Kirgis, Jr., The Degrees of Self-Determination in the United Nations Era, 88 AM. J. INr'L L. 304, 306-07 (1994) (recognizing differing degrees of self-determination, a concept consisting of many variables including the right to be free from colonial domination, the right to remain independent, the right to dissolve a state, the right to secede, the right of divided nations to reunite, the right of limited autonomy for groups defined territorially or by common ethnic, religious, and linguistic bonds, the rights of minority groups within a larger political entity, and the right to choose one's own form of government); The Right to Self-Determination: Implementation of United Nations Resolutions, Study prepared by Héctor Gros Espiell, the Special Repporteur of the Sub-Commission on Prevention of Discrimination and Protection of Minorities, at 6, U.N. Doc. E/CN.4/Sub.2/405/ 
Although preserving the culture of nations is important, I do not believe the goal of protecting the cultures of nations to require that nations exist as sovereign totalities-bounded, self-sufficient, exercising uniform control over their citizen subjects within the boundaries of their territories, with the ability to control flows across their borders. ${ }^{73} \mathrm{I}$ do, however, believe that nations deserve space, even in an environment marked by globalization, to preserve their cultural values (particularly those seen as crucial to their population). In other words, an international democratic structure would ideally permit nations to make choices or trade-offs about the decision to cede certain parts of their culture, which are not as highly valued, or whether to protect other parts, which are considered crucial.

To be sure, the nation-state today still exists and remains "sovereign" in many respects. Hence, strong versions of the globalization thesis that assert that the nation-state is an anachronism doomed to go the same way as the early modern city-state-because it no longer can provide the conditions for the economic wellbeing, security, or protection to its subjects-have not come to fruition. ${ }^{74}$ But the eager pronouncements of the death of sovereignty itself, as an empirical reality, also seem inaccurate. The modern state continues to exercise jurisdictional

Rev.1 (1980). See generally Western Sahara, 1975 I.C.J. 12 (determining that the Western Sahara was a territory belonging to no one (terra nullius) at the time of its colonization by Spain, and that the legal ties between this territory and the Kingdom of Morocco and the Mauritanian entity must be examined in the context of the social and political organization of the population of the territory); South West Africa (Eth. v. S. Afr., Liber. v. S. Afr.), 1966, I.C.J. 6 (July 18) (in which Petitioners, members of the League of Nations, argue that South Africa's use of apartheid violates the Mandate for South Africa and the Covenant of the League of Nations); Legal Consequences for States of the Continued Presence of South Africa in Namibia (South West Africa) Notwithstanding Security Council Resolution 276, 1971 I.C.J. 16, at 66-69 (June 21).

73. I have provided a description of sovereignty inspired by Krasner, who offers four meanings or categories of sovereignty: domestic sovereignty (the organization of authority and control within the state), interdependence sovereignty (the ability to control flows across borders), international level sovereignty (establishing the status of a political entity in the international system), and Westphalian sovereignty (preventing external actors from influencing or determining domestic authority structure). These categories overlap and do not co-vary in any necessary pattern. Stephen D. Krasner, Sovereignty: Organized Hypocrisy 11-25 (1999). See also Contending Sovereignties: Redefining Political Community (R. B. J. Walker \& Saul H. Mendlovitz eds., 1990); Richard Falk, Explorations at the Edge of Time (Falk ed., 1992); Held, supra note 17; Saskia Sassen, Losing Control? Sovereignty in an Age of Globalization (1996).

74. See Jean L. Cohen, Rights, Citizenship and the Modern Form of the Social: Dilemmas of Arendtian Republicanism, in 3 Constellations 164-85 (1996); Сонеn, supra note 22. 
authority, the power to sanction, and to legitimately use force vis-à-vis those in its territory. ${ }^{75}$ Furthermore, state citizenship remains a very important form of membership for many and includes interconnected issues such as belonging, power, security, culture, and status.

Hence, one of the goals when contemplating the establishment of international institutional democracy is to strike a balance between these two ends of the spectrum, and to realistically pursue an alternative to either extreme-absolute sovereignty on one end of the spectrum, and its antithesis, the total erosion of the nationstate on the other side. To ensure that nations are "autonomous" in the way that the legal and political philosopher Joseph Raz defines autonomy - that they have a sufficiently wide space of choices to make ${ }^{76}$-requires choices that permit nations to protect areas that they consider crucial to their culture, and with which they identify with being a nation, while also allowing them to communicate and coordinate with other nations. ${ }^{77}$ In my view, this would represent a true exercise of a nation's autonomy. I consider the preservation of autonomy to be a central goal in the development of international democratic institutions, and hence, one specific criterion, to use the language of evaluative institutional legitimacy described above. In addition to striking the balance between absolute sovereignty and the total erosion of the state, I prefer discussing 'autonomy' as opposed to 'sovereignty,' considering that the word 'sovereignty' is typically associated with the absolutist variant-one that claims national sovereignty stands for complete control over its subjects or citizens, on its internal and external flows across its borders, control over its territory, and independence from any external interventions. It is for this reason that some scholars such as Louis Henkin say that "it is time to slowly ease the term [sovereignty] out of polite language in international relations, [and] surely in law."

Although Raz's definition of autonomy is not directly about nations or the international system, it is easily applicable in such a context. For him, autonomy consists of the ability to make choices-more precisely, the ability to make choices within "an adequate range of options." 79 For him, it is not about achieving total control, but rather, being able to make choices. ${ }^{80}$ Currently, nations find

\footnotetext{
75. See CoHen, supra note 22.

76. What constitutes a "sufficient" space is primarily determined on an intuitive basis.

77. Joseph Raz, The Morality of Freedom 370-98 (1986).

78. Louis Henkin, The Mythology of Sovereignty, in State Sovereignty: The Challenge of a Changing World, Proceedings of the Canadian Council on International Law 15, 16 (1992).

79. See Raz, supra note 77, at 391 .

80. See id. at 381
} 
themselves having to deal with the effects of globalization, and their choices are increasingly being restricted, without their having to make trade-offs (on different issues) themselves. Rather, such choice restrictions are the result of global forces, which both small and large nations simply cannot control. As Raz states with concern, "changing technologies, economic and social conditions" make autonomy a central issue to consider. ${ }^{82}$

Autonomy for Raz is the ability to "freely or deliberately [choose] from among various alternatives." ${ }^{83}$ In other words, at an international level, autonomy consists of the ability to make trade-offs and determine how to relate with other nations, as well as determine which areas a population is willing to collaborate on and reconcile with other nations' populations, and which areas they choose not to compromise-areas where there will likely be limited negotiation, since these are seen as crucial to national identity. This idea negates the image of a sovereign nation with absolute control over its territory, and its citizens, vis-àvis other nations of the world-it is a more realistic version perhaps in an era marked by globalization. Hence, rather than protection and preservation of all facets of a nation's culture and territory, the goal of international institutional design is to allow nations the ability to understand the choices available to them, and then make decisions, or, perhaps more aptly, to make trade-offs (between competing values and concerns).

I have referred to political and cultural autonomy. I consider culture to be a more general concept, which includes the political domain, and hence, political autonomy is part of cultural autonomy. To further explain what I mean by political and cultural autonomy, I look to Mario Bunge's definition of culture. Culture is a broad concept, and includes such elements "as language, stories, knowledge (in particular science, technology, and the humanities), art, morality, and ideology-including religion.... Thus conceived, a culture is a concrete system, [and] not a bunch of disembodied ideas." ${ }^{44}$

One can argue, as Bunge does, that politics and political structures are inextricably connected to culture. ${ }^{85}$ He says that "politics cannot be properly understood without analysing both the concepts and the powers of ideology,

81. Id. at $369-70$.

82. Id. at 370 .

83. Id. at 369 .

84. Bunge, supra note 11, at 219.

85. See id. at 218. 
technology, and communication.... Hence, the need to connect political science with cultur[e]." ${ }^{86}$ Social psychologists Fathali Moghaddam, Donald Taylor, and Stephen Wright define culture in a similarly broad manner, pointing out that culture is "the human-made part of the environment," "a combination of both social and material products of humankind, [including] material products such as roads, bridges, cooking pots, and military weapons [as well as] musical symphonies, poetry, and other social products." ${ }^{87}$

In other words, Moghaddam, Taylor, and Wright would see political structures as part of culture, considering that culture is the social or material product of humans. And so if we adopt this definition of culture, then cultural autonomy consists of making choices and trade-offs in the broad, overlapping areas mentioned above.

It can be argued that my having made the preservation of a nation's autonomy important obfuscates the goal of designing international democratic institutions with protecting national autonomy. In my view, pursuing the goal of preserving nations' autonomy does not necessarily impede the pursuit of international institutional design. In fact, it can also be argued that populations of nations are less likely to participate in, or even consider legitimate (or insufficiently legitimate) institutions that do not demonstrably convince them that their autonomy is being preserved. In other words, preserving the autonomy of nations reinforces the strength and legitimacy of the international institution in question. Hence, I do not consider the goals of preserving nations' autonomy and designing a legitimate international institution to be opposed, but rather reconcilable, mutually reinforcing ones. Now, I turn to the second criterion of design: the lifting of the bifurcation between the populations of nations.

\section{Lifting the Bifurcation}

"Bifurcation," in this context, is the notion that nations' populations are separated from one another, and do not communicate with one another. I describe two varieties of bifurcation below: the state-based, executive bifurcation variant, and the democratic bifurcation variant.

86. Id. Bunge uses the word "culturology" rather than "culture," which is the title of chapter five of his book. In the text he uses the terms "culturology" and "culture" interchangeably.

87. Fathali Moghaddam et al., Social Psychology in Cross-Cultural Perspective 4, 5 (1993). 
Separating nations' populations from one another is a by-product of adopting an international system based on state-centrism. The effect is that states, and typically their executive branches, at most can inter-mediate citizens' voices when determining international law. I see the task of lifting the bifurcation between nations' populations as central to the task of designing democratic international institutions. Without the possibility of effective international communication, it is difficult for states to mutually control negative interdependencies, while retaining positive ones. The only way their desires would be made clear is for national populations to communicate and strategize with one another.

One might ask, "Why cannot the state communicate with other states to deal with such interdependencies?" While this is a valid question, states (particularly democratic states) are designed to respond to the needs of their citizens. And so the voices and decisions of citizens are mediated by local events. Considering that there are no democratic inputs from the populations of other nations, states do not know how their decisions might affect other nations, or how other nations might affect them. ${ }^{88}$

The most appropriate way to deal with this barrier to communication is to somehow lift the bifurcation. It is for this reason that I consider lifting the bifurcation a crucial criterion for institution design. And in Part III, I provide some design proposals that might lift the bifurcation, thereby allowing the populations of nations to communicate with one another.

88. It is beyond the scope of this article to show that the bifurcation causes nations to ignore the needs and concerns of other nations in the world, also reducing its rate of compliance with and enforcement of international law. See generally Andrew L. Strauss, Overcoming the Dysfunction of the Bifurcated Global System: The Promise of a Peoples Assembly, 9 Transnat'l L. \& Contemp. Probs. 489, 489-505 (1999). 


\section{a. Bifurcation Created Through State (Executive) Intermediation}

The state-centric international system ${ }^{89}$ "as presently structured relies on states, ${ }^{\prime 90}$ and more particularly, although not exclusively, ${ }^{91}$ the executive branches of states "to be intermediaries between"92 citizens of different nations. This implies that the people of the world are "not directly involved in creating international law, and the international legal order." ${ }^{\text {In }}$ Instead, the populations of nations are in a so-called "bifurcated" international system, which disassociates citizens of different nations from one another through the interposition of state or executive actors. ${ }^{94}$ And so citizens who wish to influence or participate in the creation of international law can only do so by petitioning their own government, which might or might not "respond favorably to their appeal." 95 "This bifurcated system, requiring states to intermediate between citizens and the international order," rules [of] the international system"97 — states are the actors that determine the

89. See Fairness in International Law, supra note 7, at 477-82 (explaining that the current international system is state- and executive-centric, and is far away from being described a "peoplecentred" system based on democracy); see also HeLd, supra note 17, at ch. 12 (arguing that the international system remains a "state-centred ... model," which "lie[s] at some considerable distance from what might be called a 'thicker' democratic ordering of global affairs.").

90. Strauss, supra note 88 , at 492.

91. As a generalization, the executive seems to play a significant role in international affairs when one empirically examines the way the nations of the world interact. Depending on the nation, different components of the state may likewise play a very significant role at the international level. Consider the U.S. Senate, a part of the United States' legislative branch, which plays an increasingly significant role in international matters.

92. Strauss, supra note 88 , at 492 .

93. Id.

94. See id. at 492-97.

95. Id. at 492.

96. Id. at 493.

97. Id. "The dominant view is that under the bifurcated international legal system, international law emanates from the general consent of states." Id. at 493 n.11. See, e.g., Louis Henkin, International Law: Politics, Values and Functions, 216 Recuenl des Cours 46 (1989) (proclaiming that "[i]nter-state law is made, or recognized, or accepted, by the 'will' of states. Nothing becomes law for the international system from any other source."). Although generally seen as the way that international law is created, there have been alternative suggestions about how to create international law. See, e.g., Richard Falk, Law in An Emerging Global Village: A Post-Westphalian Perspective (1998) (arguing that an increasing interest in the law of humanity and the erosion of territoriality has helped create international laws); Fairness in International Law, supra note 7, 
law. ${ }^{98}$ Bruce Ackerman disparagingly refers to such a bifurcation as an "ambassadorial"99 model "in which the peoples' voices [are] ... filtered through their national governments" 100 (executives) and states. This conception reflects the fact that "[s]tates, or more precisely those who control state power," ${ }^{101}$ decide which international laws they wish to agree to regardless of what the consensus of the population of their nation is, and even more so, regardless of the global consensus. ${ }^{102}$ Hence, this also means that nation-states do not have to consider

at 477-82 (discussing fairness as an interest that prompts the creation of international law). See also James Crawford, Democracy and International Law, 64 BRrT. Y.B. INr'L L. 113, 117 (1993) (arguing that under a state-centric system, the executive branch has comprehensive power to make treaties). Also many international scholars see international law as highly statist, which means that it vests all decision making for the creation and development of international law in the state. This version of the doctrine of state sovereignty is a complicated one and arguably originated with the Peace of Westphalia of 1648. See Louis W. Goodman, Democracy, Sovereignty, and Intervention, 9 Am. U. J. INT'L L. \& PoL'y 27 (1993); Mary Ellen Turpel \& Philippe Sands, Peremptory International Law and Sovereignty: Some Questions, 3 Conn. J. INT'L L. 364, 365 (1988); John Kuhn Bleimaier, The Future of Sovereignty in the 21st Century, 6 Hague Y.B. INT'L L. 17 (1993); M. Kelly Malone, The Rights of Newly Emerging Democratic States Prior to International Recognition and the SerboCroatian Conflict, 6 TEMP. INT'L \& Comp. L.J. 81 (1992). John Austin's ideas about international law, especially how international law comes into being are relevant when attempting to understand this bifurcation. For Austin, laws are "laws" if they are made by a "sovereign." He argues that every law flows from a determinate source. For Austin, the source of law is the state. Austin embraces this bifurcation between nations, in turn adopting what I refer to as a "state-centric" international system. See generally John Austin, Lectures on Jurisprudence (Robert Campbell ed., 1875); John Austin, The Province of Jurisprudence Determined (Wilfrid E. Rumble ed., 1995) (1832); Hans Kelsen, General Theory of Law and State 351-54 (1945) (giving a similar description of a state-centric international system).

98. See Fairness in International Law, supra note 7, at 11-13 (explaining why the international community of states as a "rule community" has created its own process for making and applying rules and resolving disputes about their meaning); see also id. at 477-82 (discussing the international system's basis on the inter relations of states, particularly the executive branch).

99. Atik, supra note 2, at 471 (citing Bruce Ackerman, The New Separation of Powers, 113 Harv. L. Rev. 633, $680(2000)$ ).

100. Atik, supra note 2 , at 471 .

101. Strauss, supra note 88 , at 493.

102. See id.

Generally speaking, states have accepted the view that they are only bound by those international laws to which they agree, either explicitly by treaty or impliedly by customary practice. This statement, however, draws upon a long tradition of discussion and debate and is subject to some qualification. First, in regard to customary 
the implications of their decisions and actions-the interdependenciesbetween their nation and another, because nations only respond and create laws explicitly for their own citizens.

international law, states have traditionally maintained that they are only bound by customary laws that they accept. The generally accepted requirement, however, for manifesting a lack of consent ("the persistent objector rule") demands that states declare their intention not to be bound by a customary law at the time of the formation of the law.

Id. at 493 (citing Luigi Condorelli, Custom, in International Law: Achievements and Prospects 179, 205 (Mohammed Bedjaoui ed., 1991)).

For a variety of reasons, this is sufficiently unlikely to happen that, practically speaking, most of the time states are considered bound by customary international law. Second, and more fundamentally, there has been an increasing, though seldom articulated, trend toward viewing customary international law as binding on even those states that have stated a desire not to be bound based upon a subtle shift to the notion that a general consensus among states binds all states.

Id. at 493-94 n.13 (citing J. Patrick Kelly, The Twilight of Customary International Law, $40 \mathrm{VA}$. J. INT'L L. 449 (2000) (discussing customary international law and arguing that customary international law is not a legitimate source of international law)). Strauss disagrees, arguing that "most states, however, do not seem to accept this view." Id. at 494 n.13. Strauss also states that:

Treaties are to an ever-greater extent replacing customary international law as the primary source of legal obligations on states. Whether a state wishes to adhere to a treaty is, under the state created rules of the international system, always voluntary. Here, however, some qualification is also in order. While a state always has the legal option to resist a treaty, as a practical matter, in certain cases diplomatic pressure may be such that a state actually has little option but to accept a treaty.

Id. (citing Robert Keohane, Reciprocity in International Relations, 40 INT'L Org. 1 (1986) (discussing the question of international norms and the role of reciprocity in creating international cooperation)). Strauss continues, stating:

The final qualification to the absolute ability of states to opt out of international law is that most states seem to accept that in certain very limited cases fundamental international norms can apply to states that do not in any way consent to be bound by them. They hold that, regardless of consent, states can be bound by natural law (some concept of absolute right) not to engage in certain basic wrongs.

See, e.g., Vienna Convention on the Law of Treaties, May 23, 1969, art. 53, 1155 U.N.T.S. 331, 334 (1969) (providing that a treaty is "void if . . it conflicts with a peremptory norm of general international law"). Peremptory norms are probably inclusive of core human rights standards. Id. at 494 n.13 (citing Lauri Hannikainen, Peremptory Norms (Jus Cogens) in International Law: Historical Development, Criteria, Present Status, Part III (1988)). 


\section{b. The Democratic Bifurcation Variant}

Suggested democratic models, which are not executive or state-centric such as the representational ones presented by Held, ${ }^{103}$ Reisman, and Franck, and discussed above, contain (although admittedly to a lesser degree than the executiveand state-dominated variant of bifurcation) a second type of bifurcation. Although democratic options are indeed an improvement over the state bifurcation variant, there is a similarity between the two: Suggested democratic models, in the same way as the state-centric (executive) model of international law, expect the population of a nation to have a representative who intermediates the concerns of her population's citizenry. In effect, just as in the case of the statecentric bifurcation variant, the population of one nation is not directly communicating with the populations of other nations. Such intermediation would not constitute, in my view, a democracy linking the populations of nations. The type of democracy linking the populations of nations requires that the populations of nations communicate and deliberate with one another directly, and not through the inter-mediation of representatives, even if they are democratically elected.

Such democratic models would enhance the bifurcation that already exists between the populations of nations, and is problematic, because the population of one nation is not necessarily expected to know anything about the concerns, values, and problems, and aspirations of the populations of other nations. In other words, this democratic, representational type of bifurcation exists as a result of the sharp separation between the populations of nations. In effect, the "voice" of each nation's population is not heard by the others.

\section{c. Lifting the Bifurcation}

One of the goals of this article is to find a way to lift the bifurcation between nations' populations. The institution design proposals that I describe in Part III below are supposed to be one (of likely many) ways to lift the bifurcation. This bifurcation occurs when there is no communication between the populations of nations to collectively consider and control two or more nations' interdependencies. The design goal is to create a democracy in which the populations of 
nations communicate directly with one another. Even if they elect representatives to represent them, lifting the bifurcation implies that somehow the process will allow populations of nations to discuss their issues and mutual concerns. This is why Held's democratic proposal does not lift the bifurcation, because, again, representatives are selected directly by a particular nation, without necessarily being required to hear the concerns and issues of other nations. Instead, the representative goes to an assembly and just "represents" his population, a population that has made demands on its representatives without direct knowledge of the concerns of the populations of other nations. In other words, the people expect their representatives to do certain things, act in certain ways, and take certain issue positions, without necessarily knowing how other national populations feel. Perhaps if the populations of nations were to deliberate together, they would take different positions, or learn from one another, thereby achieving some compromise.

\section{B. Browsing the Shopping List of Democracies In Search of Democratic Inspiration}

In this section, I will browse briefly through some democratic models that might be used as an inspiration when thinking about institutional design of an international democratic structure. At the end, I select a model of democracy which I consider to be appropriate in thinking, in guiding, and in reflecting on some preliminary proposals for the design of democratic international institutions. This part of the article consists of a brief discussion about different types of democracy in the literature, one that might be useful to think about democratic international institution design. In effect, I completed this part thinking of the international legal system as the prince in search of Cinderella by making every woman in the kingdom try on the shoe she left behind at the palace. In effect, the international system is in search of "democratic shoes" that fit. These democratic shoes would fit when they lift the bifurcation between populations of nations, while also protecting the cultural and political autonomy of nations, both large and small. 


\section{The Mega World State}

Most scholars have discounted the idea of a world state, including scholars as far back as Kant. ${ }^{104}$ However, it deserves some mention. Although it would lift the current bifurcation-since all nations are represented in a single assembly-a world state would limit the autonomy of nations, particularly smaller nations, whose voices are likely to be diluted by more powerful, more populous nations. Such democratic structures represent what Weiler would see as a strong example of adopting a "statal orientation" when conceptualizing international democracy.

However, a world or mega-state is not seen as unrealistic only for these reasons. Also referred to as global "republicanism," 105 this democratic approach is meant to create a common, shared identity between the populations of nations as a prerequisite to international governance. ${ }^{106}$ Indeed, many republican theories are based on the idea that some common identity must be forged ${ }^{107}$ to hold the world community together, typically held together through bonds of language, ethnicity, or religion- or some other shared characteristic. ${ }^{108}$ Many see this as highly problematic considering that international democracy is supposed to construct a system that allows for populations of different backgrounds and identities to participate, rather than the making of a single world nation with a single population. ${ }^{109}$ Furthermore, nations are unlikely to agree to participate in a structure that is likely to jeopardize their cultural autonomy.

\section{The "One State, One Vote" Rule of the U.N. General Assembly}

A second model, the "one state, one vote" rule is, in my view, not a democratic model at all, considering that nations vote, for example, in the General Assembly, on particular resolutions, but the governments could themselves be autocratic rather than democratic.

104. Immanuel Kant, Principles of Lawful Politics: Philosophical Draft Toward Eternal Peace 80 (Wolfgang Schwarz trans., 1988) (1795).

105. See Robert Howse, Transatlantic Regulatory Cooperation and the Problem of Democracy, in Transatlantic Regulatory Cooperation: Legal Problems and Political Prospects 469, 472 74 (George A. Bermann et al. eds., 2000).

106. See id. at 473.

107. See id. at 473-74.

108. See id. at 473.

109. See id. at 473-74. 
This approach does not lift the bifurcation between nations because the appointees are chosen by the executive. Again, through the appointee-representatives at the U.N. General Assembly, states intermediate the concerns and needs of citizens, if at all, without the populations of nations consulting and communicating directly with one another.

Also, the "one state, one vote" rule can be problematic because individuals in small states have a greater influence on decision making than individuals in larger ones, creating the possibility that decisions could be made by collaborating states representing only a tiny fraction of the world's population.

\section{Representative Democracy}

The representative democratic model does not require that all nations be represented in a single assembly, but is more modest. It suggests that international democracy is best furthered when nation-states themselves are democraticmeaning that they are based on the consent of the governed, as expressed through regular, free elections and universal suffrage, and then, the executive, through an act of representation, interacts with other nations and determines international law. This idea, inherited from liberal democratic theory, is that nationally democratically elected executives around the world intermediate the concerns and needs of the nation's citizens when interacting with other nations on the international stage.

For Slaughter and other advocates, representative democracy is a legitimate form of international governance since it is "in the hands of national citizens ... [to] hold ... governments ... accountable for their [inter]national activities." "Although this might be true, representative democracy is based on the state's executive branch, and involves the population of nations only indirectly. It does not provide for communication channels directly linking the world's national populations. And so, the approach does not fully lift the bifurcation.

\section{Suggested Models of Democratic International Institutions}

There are several international democratic institutions suggested in the literature. Consider Held, Franck, Falk, Strauss, Reisman, Innis Claude, and 
Hilary French. At the risk of seeming simplistic, one can generalize about these institutional suggestions by arguing that they all recommend instituting assemblies with a democratically-elected representative from every nation in the world, elected by the population of each nation. I will briefly comment on such approaches, and make the argument that, although I consider these approaches admirable as a starting point from which to reflect about democracy at the international level, and although they are more desirable than other models of democracy, they still do not go far enough in lifting the bifurcation between the populations of nations, and still put at risk the cultural and political autonomy of nations, particularly smaller ones.

Just as making the European Union more democratic is often viewed as requiring a strong European Parliament, making international law more democratic could entail establishing popularly elected international bodies with either general or limited decision-making powers. Proposals along these lines include those by Held to create an independent assembly of democratic peoples, ${ }^{111}$ by French to establish a body composed of representatives of national parliaments, perhaps as a transition to a popular assembly, ${ }^{112}$ and most recently by Falk and Strauss, who proposed a popularly representative Global Assembly, with representatives elected by the populations of each nation, and a simultaneous right for global civil society to lobby the assembly. ${ }^{113}$ In contrast to the "one state, one vote" rule, these options represent a "one nation, one democratic representative, one vote" rule in the context of an international assembly. These democratic options, however, do not go far enough in lifting the bifurcation between the populations of nations, since each nation selects representatives, but the populations of nations do not communicate directly with each other. Also, these institutions are so large that they risk alienating small and larger nations alike, as well as potentially jeopardizing their cultural and political autonomy. Some believe that

11. See Held, supra note 103, at 41.

112. Hilary F. French, Strengthening International Environmental Governance, 3 J. Env'T \& Dev. 50,65 (1994).

113. See Richard Falk \& Andrew Strauss, On the Creation of a Global Peoples Assembly: Legitimacy and the Power of Popular Sovereignty, 36 STAN. J. INT'L L. 191, 193 (2000); see also Richard Falk \& Andrew Strauss, Globalization Needs a Dose of Democracy, Int'l Herald Trib., Oct. 5, 1999, at 8 (advocating a new global peoples' assembly to respond to international crises); Andrew Strauss \& Richard Falk, For a Global Peoples' Assembly, Int'L Herald Trib., Nov. 14, 1997, at 8 (promoting the idea of a popularly elected world governing body); Andrew Strauss \& Richard Falk, All That Dough, PhIL. InQ., Oct. 12, 1997, at 7. 
these suggested democratic institutions potentially strengthen the voices of powerful and populous nations, while weakening those of others. Others argue that such a structure might overpower larger nations through the grouping of smaller nations. Either way, whichever argument one assumes to be true, or even, if both are accurate at different times, such institutions are inappropriate if it is our goal to preserve the political and cultural autonomy of nations.

There are less ambitious institutional models, such as that of Michael Reisman who suggests reforming the United Nations General Assembly by "parliamentarizing" it. ${ }^{114}$ Reisman quotes Franck, ${ }^{115}$ who has proposed adopting direct popular elections, which entail sending nationally elected representatives to the General Assembly, in a similar process to that of the European Parliament. However, Franck admits that the fact that state-centrism has been a central aspect of the United Nations General Assembly (U.N.G.A.) structure would pose serious challenges toward achieving such reform, even if bold and worthwhile. ${ }^{116}$

Instead, therefore, Franck develops what he calls a "modest proposal," 117 in which he recommends that the U.N.G.A. be transformed into a two-chamber body. ${ }^{118}$ One of the chambers would contain representatives appointed by states

114. See Michael Reisman, supra note 51 at 19.

115. See Fairness in International Law, supra note 7, at 483; see also Thomas Franck, Speech at the Annual Meeting of the Canadian Council on International Law, October 21, 1994.

116. See Fairness in International Law, supra note 7, at 483.

117. See id.

118. See, e.g., Proceedings of the First International Conference on a More Democratic U.N., in Building a More Democratic United Nations (Frank Barnaby ed., 1991) (describing a recent initiative with respect to the design of a Second U.N. General Assembly, sponsored by the International Network for a U.N. Second Assembly (INFU.S.A), often referred to as the "We the Peoples" initiative). Their proposals mirror those of Thomas Franck. See Fairness in InternaTIONAL Law, supra note 7, at 483-84. Robert Sheppard describes the institutional arrangements that have been recommended in the initiative:

[The initiative] mirrors many of the reforms proposed by Thomas Franck. It proposed that a democratic 'People's Chamber' be created by the General Assembly without need for redrafting the United Nations Charter by utilizing Article 22 of the Charter, which provides: 'The General Assembly may establish such subsidiary organs as it deems necessary for the performance of its functions.' The advantage of such a process would be that no new Convention to redraft the Charter would be needed nor subject to boycott by dissenting big powers unwilling to see dilution of their existing privileges. INFU.S.A has presented its proposal to the General Assembly continuously since 1985 , and a series of Non-Governmental Organization (NGO) conferences to promote the plan has been pursued under the Conference on 
(typically an executive branch appointment) similar to the way that the Assembly is constituted at present, retaining the one state, one vote principle, while the other chamber would be directly elected in accordance with universal suffrage and democratic principles. One chamber would thus give a voice to governments and the other to people. "Resolutions on important matters," which have thus far required a two-thirds majority as a result of United Nations Charter Art. 18(2) $)^{119}$ might instead "require a simple majority of both chambers." 120

Franck's approach contains both types of bifurcation: when referring to the executive-based chamber, it is clear that the executive-type bifurcation is not lifted, and the democratically elected chamber does not lift the democratic-type bifurcation. Although the second chamber does not lift the bifurcation, it is an imaginative idea, which actually adds some democracy to the international system. But, unfortunately, the voice of the first chamber would likely dilute that of the second, since the first would likely play a more significant or influential role in the overall structure, because of the historical preference for executive appointments at the U.N.G.A.. Or even if the second chamber did operate, the influence of democracy is minimal, considering the mutual presence of an appointed chamber.

But, even if one assumed that there were a United Nations second chamber, with a representative elected from each nation, the model is still inappropriate, considering that it is susceptible to inducing polarization. Consider the "NorthSouth" divide reflected in the U.N.G.A. between the very populous yet economically disadvantaged developing countries of the South, constituting a demo-

a More Democratic United Nations (CAMDU.N.). Partially in response to such efforts, the House of Commons of Canada offered to host a first exploratory meeting towards the establishment of a United Nations parliamentary assembly in 1995. The basic principle of the INFU.S.A proposals is that there should be a U.N. Second Assembly of directly elected non-governmental representatives representing all global inhabitants on a universal and equal basis as a complement to the existing U.N. institutions based on representatives of nation-states only. This would add to the democratic legitimacy of the work product of the U.N. and emphasize the collective responsibility and accountability of all governments to the collective peoples of the world. This would also facilitate dialogue between governmental and nongovernmental representatives but would not seek to supplant the nation-states or the essential elements of present state sovereignty.

Sheppard, supra note 24 , at $8-9$.

119. U.N. Charter art. 18 , para. 2.

120. Fairness in International Law, supra note 7, at 484. 
cratic majority of the world's population, and the economically advanced leading powers of the North, dominating the Security Council. In this case, such structures might overpower, through the grouping of smaller nations, the larger nations. But, it is equally possible that such a structure would potentially strengthen the voices of more powerful, populous nations, while weakening others. This proposal thus falls victim to the same weaknesses of the ideas of Held, French, Falk, and Strauss.

\section{The Public Deliberation Model of Democracy: Inspiration Toward Democratic Institution Design}

There are theories that do not presume that a shared identity is a prerequisite to developing democracy (or democratic relations). A more prominent one that has become both popular, strongly influencing recent scholarship, and enormously promising, is the public deliberation model of democracy, found in the works of Habermas, ${ }^{121}$ Amy Gutmann, and Dennis Thompson. ${ }^{122}$ This model stands for the idea that shared understanding between national populations is possible, and correspondingly, that creating a shared identity based on ethnicity (or some other shared characteristic) for instance is not a prerequisite to attaining shared understanding. It instead emphasizes rationality and communication, which, as international relations constructivists argue, is the basis for explaining why shared understandings occur between the populations of

121. See, e.g., Jürgen Habermas, Between Facts and Norms: Contributions to a Discourse Theory of Law and Democracy 287-328 (William Rehg trans., 1996) [hereinafter Between Facts and Norms]; Jürgen Habermas, Moral Consciousness and Communicative Action (Christian Lenhardt \& Shierry Weber Nicholsen trans., 1995); Thomas Risse, Let's Arguel: Communicative Action in World Politics, 54 Inr'L Org. 1 (2000) (referencing Habermas' theory of communicative action in distinguishing bargaining, rhetorical action, and truth-seeking argumentation); Nicholas Onuf, Do Rules Say What They Do? From Ordinary Language to International Law, 26 HARv. INT'L L.J. 385, 397-402 (1985) (considering Habermas in the constructivist literature); Friedrich V. Kratochwil, Rules, Norms, and Decisions: On the Conditions of Practical and Legal Reasoning in International Relations and Domestic Affairs 124, 230 (1989); Harald Müller, Internationale Beziehungen als kommunikatives Handeln: Zur Kritik der utilitaristischen Handlungstheorien, 1 ZeITschrift fur INTERnationale BeZiehungen 15 (1994) (giving a critique of utilitarian approaches to regime theory that relies heavily on Habermas).

122. See, e.g., Amy Gutmann \& Dennis Thompson, Democracy and Disagreement (1996) (expounding on the idea that when citizens disagree morally, they should work together to reach mutually acceptable solutions). 
nations (whether between states or citizens). Instead of emphasizing identity based on some shared characteristic such as ethnicity, they consider an identity based on respectful, mutual deliberation. ${ }^{123}$ It assumes that identities change as a result of "learning," 124 which is achieved as a result of deliberation, or communication with others-and hence, it is referred to as "public deliberation." 125 It is essentially premised on the idea that through communication with others, national populations can mutually sustain their autonomy and control interdependencies, by making "real choices" that they would otherwise be unable to make if they had not communicated, deliberated, negotiated with each other. ${ }^{126}$

Habermas' public deliberation democratic paradigm, ${ }^{127}$ or "communicative action," 128 is, according to him, both influenced by and genealogically traceable to Locke's ideas of "consent of the governed," 129 as well as related ideas, such as "regular and free elections and "universal suffrage." As fellow public deliberation theorist Jean Cohen also points out, the idea includes "voting, parties, [and] elections," but also supplements something to democracy: the ability for citizens to communicate directly with one another-to "facilitate ... favorable conditions for expression, association, and participation." ${ }^{130}$ Habermas concedes that public deliberation includes elections, ${ }^{131}$ but much more. As he famously put it, the goal of the public deliberation model of democracy is to establish " $[t]$ he conditions of

123. See Between Facts and Norms, supra note 121 , at 287-328.

124. See Howse, supra note 105 , at 478-79.

125. See Between Facts and Norms, supra note 121.

126. See Howse, supra note 105 , at $469,478$.

127. Between Facts and Norms, supra note 121.

128. See id.

129. See Jürgen Habermas, Three Models of Normativity, in Democracy and Difference: Contesting Boundaries of the Political 21, 28 (Seyla Benhabib ed., 1996) [hereinafter Three Models of Normativity]; see also Jean Cohen, Further Reflections on the Public Sphere, in Habermas and the Public Sphere 446 (Craig Calhoun ed., 1992). See generally Jürgen Habermas, Justification and Application (1993); Jürgen Habermas, Citizenship and National Identity: Some Reflections on the Future of Europe, in Theorizing Citizenship 255-82 (Ronald Beiner ed., 1995); Between Facts AND Norms, supra note 121, at 287-328; Jürgen Habermas, The European Nation State, Its Achievement and Its Limitations: On Past and Future of Sovereignty and Citizenship, 9 Ratio JurIs 125-37 (1996).

130. Jean Cohen, Democracy and Liberty, in Deliberative Democracy 185, 186-87 (J. Elster ed., 1998).

131. Three Models of Normativity, supra note 129 , at $28-29$. 
communication under which there can come into being a discursive formation of will and opinion on the part of the public composed of the citizens." ${ }^{32}$

Habermas' idea of democracy supplements Locke's notion of democracy with the elements of communication, and discursive will formation. In fact, Habermas sees these supplemented elements as being inspired by but not identical to the republican theses, such as that of Rousseau (discussed above). ${ }^{133} \mathrm{Hab}$ ermas does not accept the extreme version of the republican thesis; he argues that it goes too far in its requirements of solidarity and common identification. ${ }^{134}$ Rather, he argues for a middle-ground approach—one that seeks mutual understanding, communication, and consensus between the populations of nations.

In other words, the Lockean element of consent of the governed and (the Lockean-inspired element of) voting are supplemented or re-arranged with other institutional elements, when designing an international democratic institution, to ensure that communication occurs between the populations of nations. An institution that stimulates the "formation of will and opinion" of the populations of nations is, therefore, the goal of public deliberation.

Habermas' approach has influenced Gutmann and Thompson, who provide a more detailed elaboration of the notion of public deliberation. Public deliberation for Gutmann and Thompson may lead national populations "to take seriously the claims of other" ${ }^{135}$ national populations, in turn enhancing "equality," 136 and in the case of nation-states, enhancing nation-states' mutual autonomy. Gutmann and Thompson state that "[d]eliberation permits clarification of what is really at stake in disagreements between [nations' populations], allowing, for instance, identification of those conflicts that result from misunderstanding and misinformation, and that could in fact be solved without need for trade-offs between divergent fundamental values." 137 And, "deliberation also holds out the prospect of learning from others." ${ }^{38}$ In fact, it assumes that national populations come to "learn' from one another," 139 as they "come to

132. Id. at 28. See also Cohen, supra note 129 , at 446.

133. Three Models of Normativity, supra note 129, at 21, 28-29.

134. Id. at 21 .

135. Howse, supra note 105, at 479.

136. Id.

137. Id.

138. Gutmann and Thompson, supra note 122, at 43.

139. Howse, supra note 105 , at 479. 
recognize"140 ways to reconcile their needs, "and develop new views and policies that are more widely justifiable." ${ }^{41}$ Indeed, such a description has been recently empirically validated by international relations constructivists, who show how interaction between the populations of nations, as well as politicians of nations, can potentially result in mutual learning between persons or populations, as well as change in the identities of these same agents. ${ }^{142}$

Public deliberation democracy has the potential to guide the design of democratic institutions that ensure and protect the cultural and political autonomy of nations. It also has the potential of lifting the bifurcation-in turn allowing nations' populations collectively to control interdependencies-since it assumes that communication between the populations of nations is at the center of democracy. Public deliberation does not assume that democracy ought to be modeled in the image of the state-it does not assume that each nation is represented by a single person in a single global assembly. Instead, public deliberation defines democracy in a way that reorients how "representation" occurs. If communication is the central goal of democracy, then representation should be determined in ways that promote communication between the populations of nations. Having found what seems to be appropriate democratic shoes for international institutional design, in the next part, I use these insights as guidance, or more fundamentally, as a point of inspiration from which to forward design proposals.

But before starting to make institution design proposals, it is important to mention why Habermas' theory is theoretically amenable to the international level. His approach, unlike Rawls', does not assume that the population of a nation is supposed to refrain from holding deep convictions rooted in religion,

140. Id.

141. Id.

142. See generally Jutta Brunnée \& Stephen J. Toope, The Changing Nile Basin Regime: Does Law Matter?, 43 HArv. INT'L L.J. 105 (2002). Although these identities did not exist before, they are now part of the culture of the nation in question. Some might argue that changing identities does not preserve cultural autonomy, but this is inaccurate since cultures change through their interactions. My definition of autonomy presupposes that changes do occur, and these changes might arise from interactions with other cultures. See Part III infra. The point of my definition is that it is better if such changes occur as a function of the choices of a nation's population. 
conscience, or philosophy. ${ }^{143}$ For Habermas, nations' populations should communicate with one another, without being expected to rid their identities of content, and without necessarily becoming a community of nations, as members of a mega-state. ${ }^{144}$ Basing an international institution on public deliberation is, therefore, less likely to be accused of being a veil for the imposition of a particular set of values on the populations of the world's nations.

143. See Jutta Brunnée \& Stephen Toope, International Law and Constructivism: Elements of an Interactional Theory of International Law, 39 Colum. J. Transnat'L L. 19, 63 n.192 (2000), Brunné and Toope give the following comments on Rawlsian theory:

The specificity of culture is almost wholly eviscerated in Rawlsian theory ... and posits that all that is required for successful liberal politics is an 'overlapping consensus.' While this new approach would seem at first to represent a deep pluralism, the consensus Rawls describes can only be achieved if, for the purposes of public argument, subjects refrain from invoking any deeply held convictions rooted in religion or philosophy. They must simply accept 'the fact of reasonable pluralism.' [And] Rawls extends this analysis to the international realm (on the concept of 'toleration' of non-liberal peoples).

Id. See John Rawls, The Law of Peoples 59-78 (1999) [hereinafter The Law of Peoples]; see also Thomas M. Franck, The Empowered Self: Law and Society in the Age of Individualism 48 (1999) (giving a mirror image version of the "community of communities"). "Not only is Rawls' notion of the 'overlapping consensus' unrealistic if people hold their beliefs to be 'true,' it fails to explain why all comprehensive views are excluded from public discourse, except the one that treats 'justice' as the only appropriate value for social organization." Brunnée \& Toope, supra. See also Michael Sandel, Liberalism and the Limits of Justice 184-218 (2d ed. 1998). "[Even] Rawls admits that his vision of 'justice' as the over riding social virtue can leave 'gaps' for the [populations of different nations]." Brunnée \& Toope, supra. See Rawls, supra at 126. "For Aristotle, unlike Rawls, justice is only one of the virtues, and it is generally inferior to friendship." Brunnée \& Toope, supra.See Aristotle, [The Nichomachean] Ethics V:I, at 171, and VIII:1, at 258 (J.A.K. Thompson \& Hugh Tredennick trans., rev. ed. 1976).

144. Another opinion on the idea of nations of the world forming a "community" is that of Thomas Franck, who tried to avoid the problem of identifying an "international community" by describing the international community as "secular," rather than "moral" community. The secular community is assumed to share certain values such as promotion of trade, protection of the environment, economic development, communications and peace. But, one can argue that these values are themselves rooted in moral (or at least ethical) assumptions associated with specific cultural attributes, so Franck's attempt to evade this problem seems to have failed. See Franck, supra note 32, at 51, 181. Later, Franck changed his argument, informing us that procedural fairness (legitimacy) did not depend upon any notion of community, but that substantive fairness (distributive justice) was "rooted in the moral values of the community in which the legal system operates." Fairness in International Law, supra note 7, at 8, 26. Franck's idea of "community" is relatively thin and arguably appropriate as a basis for the design of a democratic international 


\section{Design Proposals Toward Global Democracy}

The goal of this part is to describe some design proposals that have the potential to lift the bifurcation, while maintaining the autonomy of nation-states. The idea is to provide some specific design proposals for the international level in order to stimulate a discussion on the topic of international institution design.

Habermas' public deliberation model inspires these design proposals. (discussed in Part II). Habermas' description of democracy as communication linking the populations of nations, ${ }^{145}$ which eventually results in shared understandings, without such populations necessarily being part of a shared community based on "thick" values, provided me with a promising starting point from which to think about international democracy, as well as a point of inspiration to guide my thoughts as I went from institutional mirage to institutional proposal, hopefully toward institutional completion in a subsequent article.

Although it is difficult precisely to enumerate all the benefits that accrue from a paradigm such as Habermas', I believe there are two central reasons why it is useful as a guide for institution building. ${ }^{146}$ For one, it bases democracy on communication, and not on any specific design or institutional requirements in the same way that representative democracy, for example, does, thereby enhancing the creative possibilities and flexibility for designing institutions. ${ }^{147}$ Second, it does not have an explicitly statal orientation, ${ }^{148}$ as Weiler would put it, and therefore, it does not make any assumption about nations having to participate in a single State structure, and thereby potentially harm the autonomy of smaller nations.

institution. Franck's conception of community is largely contractarian, even though he includes "shared values." This parallels John Rawls' ideas of deontological liberalism. See John Rawls, Political Liberalism (1993); The Law of Peoples, supra note 143, at 32, 113 (discussing the overlapping consensus, and the growth of mutually caring societies). One could speculate that as a result of the thinness of Rawls' and Franck's conceptions of community, Franck was able to claim a burgeoning global "moral" or "rule" community. See FrancK, supra note 32, at 11-12. Nonetheless, Franck's approach is inappropriate as a foundation for contemplating international institutions. Since it is based on Rawls' ideas of the international level, it is based on "state consent", and reflects the executive (state) bifurcation variant. See part III infra.

145. See Three Models of Normativity, supra note 129.

146. I use the words "institution building" and "institution design" interchangeably.

147. See Between Facts and Norms, supra note 121, 287-328.

148. WEILER, supra note 8, at 279. 
I propose designs to lift the bifurcation by creating a system based on direct communication between national populations. I should make clear that my goal is rather modest; it is not to lay out a detailed description of an alternative institution, exhaustively listing each design proposal required for its overall completion. Held cautions against taking such a path when embarking on democratic institution design, reminding us that "institutional solution[s] to the problems of democracy in the global order" are very difficult to envision. ${ }^{149}$ Keeping this in mind, the goal is to show that it is possible to imagine new directions, by providing some design proposals-in other words, elements of an overall institution. To put it simply, the goal is not to arrive at institutional completion, but rather to provide some proposals as a prelude to further research on international institution design.

Some might see the project of designing international institutions as politically ambitious. Held, commenting on the relation between feasibility and ambition, says that "political feasibility"150 should not limit political ambition, "[for] what is ambitious today might prove feasible tomor row." $\mid 51$ In light of this, Held also cautions us that when embarking on institution design projects, one should distinguish between changes that serve as short-term objectives, "such as reform of the U.N. Security Council, and changes that can serve as long-term objectives, such as the creation of global popular assembly"152 Indeed, I see my project as long-term; first, stimulating discussion, followed by further research, and maybe later, institutional changes, after arriving at a complete, and appropriate institutional design.

The goal of my design project is to reach an optimal mix between utopia and reality. ${ }^{153}$ But if this is so, why not remove this part, where I provide actual proposals, and instead simply end with a research agenda? I thought a great deal about this question, and, with all humility, I believe that the best way to persuade someone to participate in a design project is to provide some proposals that reveal that it might be possible and worthwhile to design such an institution. By making some proposals, I hope at the very least to show that it is possible to imagine international democratic institutions that meet some of the design principles described above.

149. HeLD, supra note 63.

150. Id.

151. Id. at 285.

152. Id. at 279-80.

153. See Edward Hallett Carr, The Twenty Years' Crisis: 1919-1939, at 94 (2nd ed. 1945). 
When contemplating institution design, my thoughts persistently led to the same question: Who are the actors involved? Or, who are the "governed" and those who "govern," to put it in the parlance of democratic theorists. Related questions, such as "Who are the voters?", "Who are the representatives?", and "Who elects whom?" are the central questions on which a democratic institution is built. After all, as Anthony Giddens, a sociologist who studies institutional structures, shows, an institution is based and determined by its agents and their "relational interactions." ${ }^{154} \mathrm{He}$ furthermore argues that the identities and roles of those agents define and make up the institution. ${ }^{155}$ Hence, I describe who the actors are and what roles these actors play, and how they relate.

As a note of caution, it can be argued that the way in which the following sub-sections are divided is artificial, considering that all the principles and explanatory points inter-relate, mutually and reciprocally influencing and reinforcing one another; without one, another principle does not make sense. In other words, the principles mutually presuppose one another, and are meant to mutually achieve an overall picture. Of course, other scholars might order these thoughts differently, and I welcome such a debate.

\section{A. Elected Representatives Representing Two Nations Simultaneously: Changing the "One Representative, One Nation" Rule to "One Representative, Two Nations"}

To develop or design an international democratic institution is challenging, and requires complex approaches. Finding ways to design institutions that engender shared understandings, and that allow representatives to hear each other's concerns without creating polarization between nations requires a structure that is premised on a more distinctive principle of equality than the one manifested in the "one state, one vote" doctrine of the U.N.G.A., or the "one state, one democratic representative, one vote" in a democratically established assembly, such as the one suggested by Held. Considering that each nation wishes to conserve its cultural autonomy, polarization between nations is

154. Anthony Giddens, The Constitution of Society 2-3, 16-19, 22-28, 36, 83-87, 132-39, 162-65, 179-80, 281-84 (1984) (providing a helpful review of basic concepts) [hereinafter Constitution]. See Anthony Giddens, A Contemporary Critique of Historical Materialism: The Nation-State and Violence (1981) (applying structuration theory in an analysis of the emergence and continuing force of the nation-state).

155. Constitution, supra note 154. 
expected to become a common phenomenon-making it difficult for nations to come to agreement about important issues. However, such polarization might not result if we adopt a different principle of equality-not the version of equality that implies that a single person represents a specific nation, whether appointed by the executive, or elected by the people to represent them in an assembly, the version based on domestic sphere democracy. ${ }^{156}$ Citizens of national democracies typically vote for a single candidate based in a specific geographic area. For example, only Arizonans vote for U.S. Senator John McCain. Transposing this approach to the international level, wherein each nation sends a single representative to serve in an assembly, is based on what Barkun would call a "false analogy" between national and international levels. ${ }^{157}$

Even scholars such as Franck have used national analogies to conceptualize international democratic structures and processes-and this is not an uncommon feature of the literature. Consider Franck, whose international democratic alternative is to create a second chamber in the U.N.G.A., popularly elected with representatives (of different numbers, for proportionality) from each nation. ${ }^{158}$ For Franck, electing one representative per nation smacks of unfairness, since larger nations receive the same attention given to very small nations. Instead, he proposes an "allocation of seats corresponding generally, if not absolutely, to population size, in the same way as do many democratic nations at the domestic level" (who vote on the basis of "weighted voting"). ${ }^{159}$ This approach is directly inspired, as Franck admits, by the way some domestic democracies allocate seats, increasing the number of seats for a particular district or region if its population is higher than other ones in the nation. ${ }^{160}$ While Franck's approach might create international democracy, it triggers new, perhaps even dangerous problems, primarily because nations represented in a single assembly differ from Franck's artificial "districts." Consider how smaller nations will allege that their culture is being determined by the decisions of larger nations, ${ }^{161}$ exemplified in the Danes' reactions to EU Directives.

156. See Barkun, supra note 8, at 11.

157. See id.

158. See Fairness in International Law, supra note 7, at 479-80, 483-84.

159. Id. Consider Canada and the United States, which each have federal systems that are inspired by a "weighted voting" philosophy.

160. See id.

161. See id. 
Perhaps contemplating the question of international democracy requires us to move away, even for a while, from national systems and metaphors of democracy as Weiler suggests in his writings. ${ }^{162}$ Again, what is being sought is an approach or structure that permits and induces communication linking the citizen populations of nations. If this communication is achieved, the bifurcation problem would be lifted. But it is also crucial to remember that the ability of nations to create relationships with one another through deliberation processes must not be achieved at the expense of smaller nations, whose participation in a democratic institution at the international level puts their political and cultural autonomy at risk.

But, what exactly is required to lift the bifurcation between nations? A bifurcation, as explained above, occurs not only when citizens operate in a statecentric model, wherein they are required to intermediate their concerns through state officials. Even democratic models such as the one suggested by $\mathrm{Held}^{163}$ contain a type of bifurcation: Populations of nations are expected to vote for a representative that they want, without necessarily considering the concerns, values, problems, and aspirations of other citizens abroad. In other words, there is a sharp separation between the populations of each nation-each population's "voice" is not heard by the other. They therefore have a greater likelihood of sending representatives who are not sensitive to the concerns and issues of other nations, thereby potentially exacerbating polarization and inducing disagreement. People are reasonable and once they consider proposals that could serve the interests of both nations, they would likely find ways to compromise and reconcile their mutual interests and values. ${ }^{164}$ However, if elected representatives were from a single nation, the options would likely be skewed toward the concerns, interests, values, and aspirations of only that nation. This would in turn make it difficult for the representative to compromise, which is essential if the goal is to develop shared understandings between populations.

Hence, in order to foster shared understandings which would protect the cultural and political autonomy of nations, politics at the international level would have carried out differently. To do this, it becomes important to change the one representative per nation, or the one nation, one vote principle.

162. WEILER, supra note 8 , at 279.

163. See Held, supra note 103, at 40-41.

164. See generally Brunnée \& Toope, supra note 143 (describing how citizens tend to abide by reasonable things that are asked of them). 
While most scholars see either of these ideas as part of their models of international institutional democracy, there is no need to be so confined. Of course, for scholars such as Held, the idea of one nation, one representative is deliberate, and is meant to ensure equality between nations. But although equality can be defined as the adoption of a single representative from every nation, it is also possible to define equality as having two voices of equal strength in a single personin other words, two cultural identities are simultaneously represented in the same representative. In the era of hyphenated identities, ${ }^{165}$ migration, and multiculturalism, it is common for people to participate simultaneously in two or more cultures, national or otherwise. This is consistent with international relations constructivists' position that "constructed actor identities are not monolithic; actors may maintain and foster multiple, though typically overlapping, identities ${ }^{166}$ depending upon the pattern of interactions into which they enter." 167

Indeed, this type of equality is consistent with democracy, because fundamentally, as Cohen and Habermas point out, democracy is "voice," and is based on interpersonal communication. There is nothing that necessarily requires that international democracy consist of national representatives, each elected by their respective nations' populations. Instead, more imaginative approaches are possible, which include having one representative represent two nations simultaneously, what I refer to as the "One Representative, Two Nations" principle. In fact, it can be argued that even in national democracies, representatives express two voices or identities. Consider how United States Senators represent their states, yet also determine the fate of the nation as a whole. Each of these federal representatives not only represents the larger nation, but also decides the fate of the local geographic district from which she was elected. These identities are fused in the minds of the representatives and are part of their agency. The representative balances and reconciles the needs of her district with those of the nation as a whole. This undoubtedly requires creativity on the part of the

165. Examples of hyphenated identities include identities such as Canadian-Italian, or MuslimFrenchman, etc.

166. For explanations of identities, see for example, Alexander Wendt, Anarchy Is What States Make of It: The Social Construction of Power Politics, 46 INT'L ORG 391, 398 (1992); SANDel, supra note 143, at 15-65, 130-31 (2d ed. 1998); Emanuel Adler, Imagined (Security) Communities: Cognitive Regions in International Relations, 26 MiLlenium J. INT'L STUd. 249 (1997) (using the term "multiplicity of allegiances").

167. Brunnée \& Toope, supra note 143 , at 31 . 
representative, and an ability to examine and discern the different interests of the distinctive regions.

In the same way that this occurs at the domestic level for U.S. Senators, it is possible for an international democratic institution or institutions to contain representatives elected by two nations simultaneously. In other words, each representative has voices belonging to two nations and she represents both nations.

\section{B. Simultaneous Voting: An Explanation}

If representatives have two voices, how are they democratically selected? As stated above, representatives are not selected on the one nation, one representative principle, but on the one representative, two nations principle. But, how does the voting system operate, such that representatives represent two nations simultaneously?

Representatives represent two nations simultaneously because both nations vote simultaneously for the same slate of candidates. The candidate who receives the highest number of votes of both nations becomes the elected candidate, and will serve, as a representative for both nations.

For example, consider the case of a person, a Canadian national citizen and resident, who wishes to serve both Canada and Germany-he feels that he understands German issues and learned German as a second language while at university. ${ }^{168}$ To serve both nations, he must run in an election linking Canada and Germany ${ }^{169}$ —an election in which all citizens of voting age of both countries have a right to participate-and win the greatest number of votes over all other candidates running.

\section{Citizens of Nations are the Voters in Elections}

Again, it is important to emphasize that those who vote for representatives are the citizen populations of nations. In the electoral race, which includes

168. This is a purely hypothetical example of a person who is interested in running for elections at an international level. It does not represent any formal qualifications required to run. For example, a person may not even speak German, and nonetheless be elected by the German people. 169. When we use the word elections "between," I mean that both nations' citizens are participating in electing a particular candidate from the same slate of candidates. 
Germany and Canada, the populations of Germany and Canada simultaneously vote for one of the many candidates running for the Germany-Canada seat.

This election process enhances communication between the populations of nations and lifts the bifurcation that exists in the current state-centric system. The populations of nations would be able to communicate with one another without the veil of state-centrism separating them from each other. Before electing a candidate to represent their mutual national populations, they would have to communicate with and listen to the concerns of other national populations, and perhaps even come to resolutions and determine a shared future course. This is not to say that such an approach induces a republican-style identity linking separate national populations. Instead, the populations of different nations would relate on the basis of a civic or political association ${ }^{170}$ to preserve each other's goals and aspirations (as per their particular conceptions of legitimacy), without infringing, or infringing as little as possible, on the cultural autonomy of one another. In other words, this interactive process allows the populations of nations to potentially develop shared understandings. But in addition, it also affords the opportunity for separate national populations to forge relationships, which might allow them to identify with one another, even if it is a narrower form of identification when compared to the level and degree of identification at a national level (as represented by a republican conception of democracy). These new identities would likely be relational identities, and not identities that aspire for cultural or political unity. Instead, identification between different national populations would likely amount to respect for comity. This form of identification, although certainly not as strong as republican notions of solidarity and collective identification, is also likely to support the development of future laws and mutual regimes, thereby further reinforcing democracy.

The "governed" in this case consists of the populations of both nations, who together, during the pre-election campaigns, engage one another and deliberate. This allows three inter-related dynamics to emerge. First, this might result in greater rapprochement between the two peoples, who would likely communicate in a deliberative manner as they mutually select candidates. Second, the representative who undergoes the campaign experience would likely learn the interests and values of both nations that she intends to represent, and find ways to reconcile them. Third, the candidate that is elected would be expected to 
continue this process of reconciling the values and interests of the nations that she represents, if she wishes to be re-elected.

Furthermore, laws created by representatives elected by two national populations would likely reflect the popular consent of the participating nations. The laws would therefore likely be perceived as legitimate because they would represent a reconciliation of the nations' values and interests. In other words, national populations would likely see the law as "ask [ing] for reasonable things." 171

\section{Toward the Adoption of One International Assembly Per Nation: Changing "All Nations, One General Assembly" to "One Nation, One Assembly"}

But having representatives elected from two nations, although important, is not by itself sufficient to constitute an institutional design. Such representatives should arguably be elected to a mega-state assembly, as part of the development of a world demos. But, as discussed above, this is inappropriate, and perhaps unrealistic. Indeed, although having representatives elected from two nations helps preserve cultural autonomy in a hypothetical democratic international institution, it does not go far enough. To further protect the cultural and political autonomy of nations, while affording their populations opportunities to communicate and relate directly with one another, another design principle is required-the principle of "One Nation, One Assembly" to replace the commonly held principle of "All Nations, One General Assembly."

Almost all proposals by contemporary international democratic scholars see the inclusion of all nations' representatives in a single body-what I refer to as the "All Nations, One General Assembly" principle. This principle is inappropriate, since it increases the potential for polarization of views, disagreement, and potentially results in the silencing of less powerful nations. Also, it does not lift the bifurcation, because the populations of nations do not inter-relate directly with one another, but rather through the intermediate of an elected representative. This means that the population of nation $\mathrm{X}$ has not necessarily considered and heard the concerns of nation $Y$ before selecting a particular representative.

In addition to the issue $I$ have presented, there is a second issue, of technical importance, which is, if a potential representative is elected by two nations'

171. Brunnée \& Toope, supra note 143, at 52-56 (citing Lon L. Fuller, The Morality of Law (rev. ed. 1969). 
populations, then in what institutional structures are they represented? Let us consider the mega-state assembly for the 191 states in the world for the sake of demonstrating the difficulties associated with this issue at a technical level. Since each nation would jointly elect one representative with each other nation, this implies that each nation sends 190 joint representatives. When one then totals all the nations together, this comes to a net of 191 times 190, or 36,290 representatives. Clearly, adopting a system with a single assembly is highly inappropriate, but there is another approach, which solves this problem of cumbersome numbers, while simultaneously furthering the goal of preserving nations' autonomies: the "one nation, one general assembly" principle.

I propose to replace the "All Nations, One General Assembly" principle with the "One Nation, One General Assembly" principle. The "One Nation, One General Assembly" principle stands for the idea that each nation possesses an assembly with representatives elected in the process described above: Each assembly contains 191 representatives elected from the nation where the assembly is located, with each jointly elected by another nation. But, let us put the election process aside for now, which will have to be the subject of a follow-up article.

Until now, the literature on international democracy has consistently assumed, probably as a result of the "statal" orientation enunciated by Weiler, or what Barkun, more precisely, refers to as the national analogy, that all nations of the world ought to be represented in a single body wherein representatives vote on different issues. But, why not have an assembly in each nation with representatives elected both by the population of the nation and another nation (like the first principle discussed in Part III.A.). Considering that there are 191 nations, there would be 191 representatives in each assembly.

By having an assembly in each nation, this, in addition to solving the technical issue of size, allows representatives to live, see, and feel the needs of the nation in which they reside, thereby further allowing them to understand the issues, and producing the effect of inducing reconciliation. But more importantly, it affords the opportunity for each representative to be elected by the population of their own nation as well as the population of another nation. Each representative in the assembly would seek to find ways to reconcile the needs, values, and interests of the two nations from which they were elected. This mechanism would also allow the population of one nation to communicate with another nation's population through the election process. This would undoubtedly lift the bifurcation, since nations are simultaneously voting for a candidate to mutually represent them. 


\section{E. Design Proposals Wanted: Toward Institutional Completion}

Of course, even when taken together, these design proposals are minimal. They are meant to provide an idea about how international democracy could be designed. Of course, to complete the institution design, many more proposals are necessary. My hope is that by outlining some preliminary design proposals, I have opened the doors of academia to a new research agenda of international institutional democratic design.

This research agenda includes many questions that require answers. First, how long should each representative serve in this assembly? Then, what are the potential interactive effects between such an assembly and domestic States structures? What are the potential effects of the structure on representatives in any single assembly? What are the number of electoral races between national populations? Which representatives serve in the assembly? How are votes tabulated and how are winners selected? How do laws become binding? Are laws based on force or on persuasion? Of course, there are many more additional questions to consider about designing an international democratic institution--a discussion I welcome and encourage.

\section{Conclusion}

Globalization has inaugurated a period of interdependencies, both positive and negative. This has in turn consolidated the destinies of nation-states. Indeed, the realization that the fates of nation-states are increasingly interconnected triggers questions about whether the global system is legitimate-and if not, why it is not.

The response to this latter question is inspired by the realization that interdependencies cannot be prevented, given Strauss' notion of bifurcation, in which national populations are divided from one another. This can be seen as a design flaw-an architectural defect of the global system.

To deal with this design flaw called bifurcation, my project contemplates redesigning the global system in ways that take into account the everyday realities of nation-to-nation interdependencies. I admit that design is complicated, requiring one to think about varieties of alternatives, each with their own pros and cons, and each having different effects. My goal in this article however was to show, or rather, to hint how it might be possible to overcome or neutralize the bifurcation 
between national populations by making some institutional design proposals. By making these proposals, I hope to stimulate further research in the area.

Considering that interdependencies seem to exist, it becomes crucial to examine the possibilities available for structural global change. Also, I should say that talking about interdependencies as a concept is more useful than globalizationglobalization might not be a fact, considering that a nation might not want to embrace its offerings. On the other hand, interdependencies-whether or not caused by this thing called 'globalization' - exist, and to control them requires mutual action on the part of nations and their populations. The overall goal, then, is for the population of nations to communicate with one another, thereby inducing greater possibilities of listening, of learning, and of decision making, with the hopeful result of yielding mutually effective solutions to the globe's nascent problems. 


\section{HOW CONERESSWORIS AND WHYYOU SHOUID GARE}

Lee H. Hamilton

An inside look at the way Congress works and how it impacts the lives of all Americans, by an eminent former Congressman. cloth $\$ 29.95$ paper $\$ 14.95$
LEE H. HAM I LTON

HOW

CONGRESS WORKS and

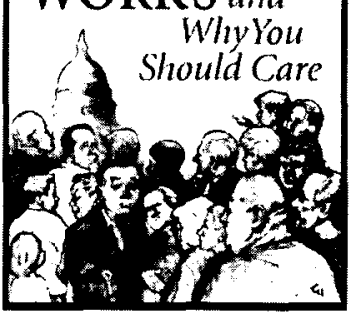

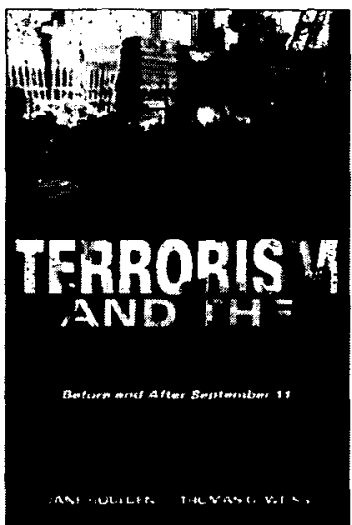

TERRORISMAND THE UN

Before and After September 11

Edited by Jane Boulden and Thomas G. Weiss

An up-to-date assessment of the UN's changing role in the international war on terrorism.

cloth $\$ 60.00$ paper $\$ 24.95$

\section{RUSSIAN PEASANTS EO TO EOURT}

Legal Culture in the Countryside, 1905-1917 Jane Burbank

A pathbreaking study of the legal culture of Russian peasants in the closing years of the Russian Empire. cloth $\$ 49.95$

\section{INDIANA UHIUERSITY PRESS

